\title{
THE SETTLEMENT OF THE BADEN CULTURE AT SITE 1 IN ZOFIPOLE, KRAKÓW DISTRICT (RESULTS OF EXCAVATIONS CONDUCTED IN 1986)
}

\begin{abstract}
Dobrzańska H., Wilczyński J. and Zastawny A. 2016. The settlement of the Baden culture at site 1 in Zofipole, Kraków district (results of excavations conducted in 1986). Sprawozdania Archeologiczne 68, 223-262.

Site 1 in Zofipole east of Kraków is known for long-standing research conducted in 1930 s and 1940s. In 1986 test excavations were conducted in the eastern, up to then unrecognized part of the area. This research led to the discovery of a part of a small settlement of the Baden culture yielding interesting and diversified (while not numerous) sources for studies into this culture in Lesser Poland. This research is worth discussing due to new radiocarbon data, animal bones analyses, the discoveries of a dwelling feature and presumed symbolic burial and fragments of pottery for salt production.
\end{abstract}

Keywords: Eneolithic, Baden culture in Poland, settlement materials, environment reconstruction, archaeozoological analysis

Received: 19.02.2016; Revised: 08.04.2016; Accepted: 06.05.2016

\footnotetext{
* Institute of Archaeology and Ethnology Polish Academy of Sciences, Sławkowska st.17, 31-016 Kraków, Poland

** Institute of Systematics and Evolution of Animals Polish Academy of Sciences, Sławkowska st.17, 31-016 Kraków, Poland

*** Archaeological Museum in Kraków, Senacka st. 3, 31-002 Kraków, Poland
} 


\section{INTRODUCTION}

The multicultural site 1 in Zofipole, Igołomia-Wawrzeńczyce commune, is located in the Vistula river basin on a loess flood-plain of the left-hand bank of Vistula, 28 kilometres to the east of Kraków (Fig. 1). Archaeological artefacts derive from long-standing excavations conducted in the $20^{\text {th }}$ century. Site 1 in Zofipole was excavated in 1934-1935 (J. Bartys) and in 1946-1949 when the research was managed by T. Reyman (Archaeological Museum of the Polish Academy of Arts and Sciences) with the participation of S. Buratyński and A. Żaki.

The research was conducted west of a Pleistocene stream cutting through the loess floodplain (Fig. 1). For many years this area was described in the literature as site 1 (Nosek 1967, 117-118). In the 1980s, in the scope of the Polish Archaeological Record Project, field surveys were conducted inside Zofipole limits and as a result site 1 was enlarged with the territory located east of the mentioned stream. The range of archaeological artifacts within the site encompassed circa 18 ha (Fig. 1A).

Without going into details as to why the areas west and east of the stream were joined within one site, it should be mentioned that materials of the Baden culture were registered only within its eastern part (Fig. 1A, C). The site of the Baden culture described in this work was discovered during rescue excavations conducted in 1986 (Fig. 1B, Fig. 2) under the management of H. Dobrzańska in cooperation with W. Morawski from the Institute of the Archaeology and Ethnology of the Polish Academy of Sciences (see: Informator 1987).

In 1997, in the western part of the site in Zofipole, two pottery kilns dated to Roman period were excavated. Both kilns were registered during the geophysical prospection conducted at the site in 1996 (Dobrzańska and Herbich 2004).

\section{MODERN GEOGRAPHICAL ENVIRONMENT}

The settlement of the Baden culture in Zofipole, site 1 is located in the Vistula river basin on a loess terrace flattering, circa 10 metres above the bottom of the Vistula floodplain (Fig. 1C) and 1.8 kilometres from its modern channel. This area is situated in the western part of the Sandomierz Basin (Czeppe and German 1980). To the north, the Vistula river valley is limited by an erosive edge of the Proszowice Upland. The erosive relief of these areas formed on Miocene clays is covered with diversified Quaternary sediments. The largest area is encompassed by loess uplands and high river terraces /8-12 and 15-25 metres (Tyczyńska 1968). The bottom of the Vistula River is 4-5 metres below the level of the flood plain 3-7 km wide. The flood-plain is composed of a wide range of multi-age segments with numerous paleomeanders preserved in its relief (Kalicki 1991a, 2006).

Soils refer to various Quaternary sediments with fertile "chernosems" and brown soils covering the loess terraces, while alluvial and hydromorphic soils occur on the river flood plain (Klimaszewski 1979, 16). 

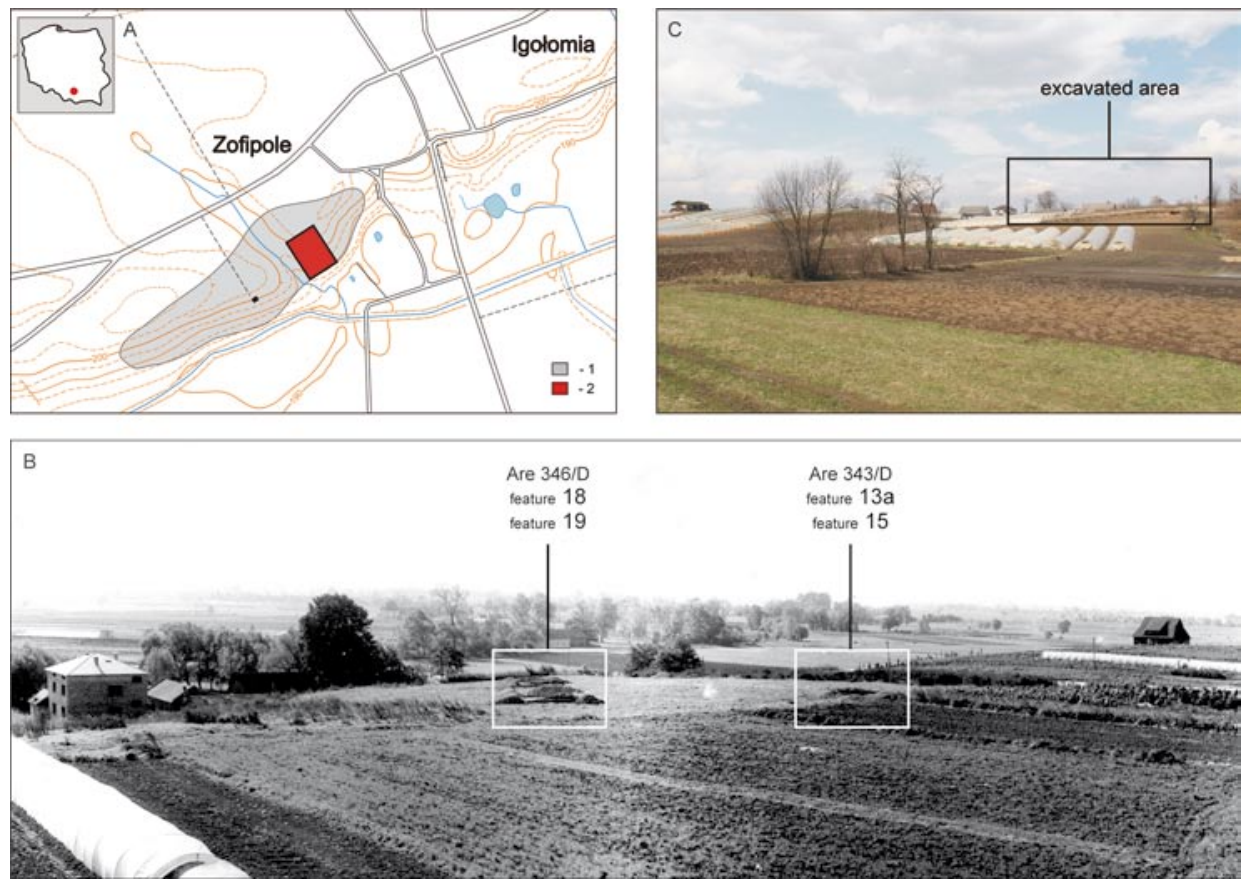

Fig. 1. Zofipole, site 1, Kraków district: A - location of the site with its range marked according to the documentation of the Polish Archaeological Record Project (1) and the area of the archaeological research in 1986 (2), B - view from the north-east taken during excavations in 1986 with the location of excavation units including features of the Baden culture (photo by W. Morawski), $\mathrm{C}$ - the current view of site 1 in Zofipole - photo taken from the south-east (photo by A. Zastawny) 

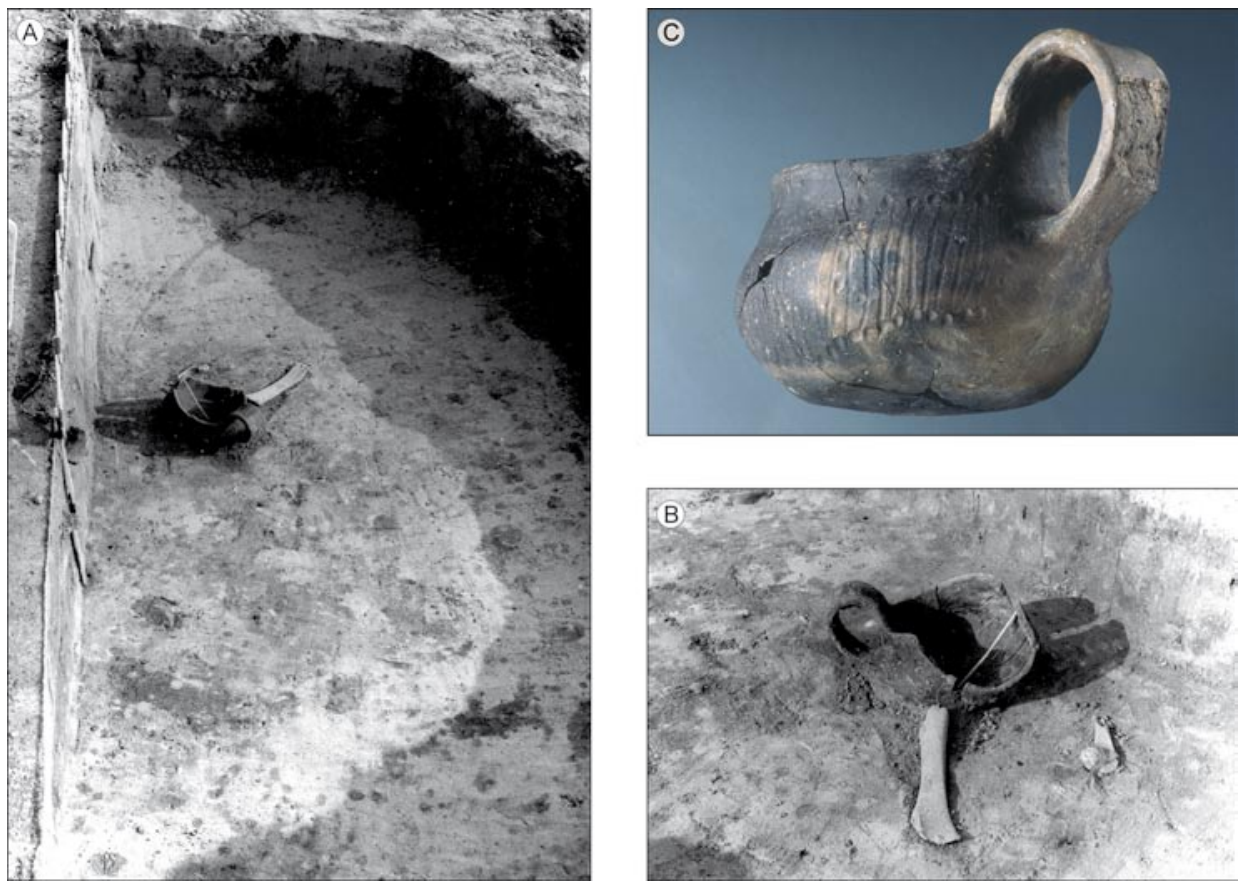

Fig. 2. Zofipole, site 1, Kraków district. The cup of the Baden culture from feature 18: A, B - level of the discovery during exploration in 1986 (photo by W. Morawski), C - the vessel after its reconstruction (photo by R. Słaboński) 
Natural vegetation within the discussed area was almost completely destroyed by human activity. Nowadays, this area is being cultivated and used agriculturally. Potential natural vegetation consists of oak-hornbeam forests within higher and drier habitats, willow-poplar, elm and alder-ash riverside forest in the bottom of the valley (Klimaszewski 1979, 17).

\section{GEOGRAPHICAL ENVIRONMENT IN THE BADEN CULTURE PERIOD}

The Vistula river valley situated east of Kraków is one of the best recognized areas in Poland on account of its paleography. Analyzing the archaeological exploration of this area, we know that it has been settled from the beginnings of the Neolithic up to now. Such a favourable situation enables us to reconstruct some elements of the paleoenvironment and even to investigate the interactions between human beings and the geographical environment.

Crucial changes concerning the Vistula river valley occurred at the close of the Atlantic and in the beginning of the Subatlantic. On the river flood-plain, east of Kraków, at the close of the Atlantic, the flood phase was noted. Overbank deposits (flood muds) were covered with organic sediments (Kalicki et al. 2005). Several meanders were cut off (Kalicki 1991a, b, 2006; Starkel et al. 1991). The most essential changes of the river channel occurred later and were connected with two avulsions of the Vistula river. The first one is dated to circa 5090 \pm 110 BP (4226-3651 cal BC) in Grobla Wood (Starkel et al. 1991; Kalicki 2006), the second one is linked with the period $4410 \pm 130$ BP (3506-2694 cal BC) in the area of Wola Batorska-Zabierzów Bocheński (Kalicki et al. 1996; Kalicki 2006, 143). Upstream from Niepołomice, the Vistula river moved from the loess terrace to the south whereas the change of the direction of the Vistula flow from W-E to SW-NE downstream from Niepołomice was a result of the two avulsions of the riverbed to the north. The meander belt, with a width of 2-3 $\mathrm{km}$ along the present-day river, began to develop. The straightening and shortening of the course of the Vistula river initiated the process of vertical erosion. The consequences of these changes were noticeable up to the turn of eras when the river bed incision reached its maximum and caused the drying of the habitats of the flood-plain (Dobrzańska and Kalicki 2003, 2004; Kalicki 2006, ryc. 31: A).

Summarising the above-mentioned remarks, we should emphasize the increase in the activity of the Vistula river in the period of the Baden culture. It should be synchronized with the period indicated by the radiocarbon dates obtained for features in Zofipole (features: 13a, 18) - about 3000 BC. One of consequences of this activity are fallen trees whose trunks were discovered in alluvia. Paleobotanical data obtained for this period indicates a humid climate (Fig. 3), presumably not very cool - evidenced by the presence of freshwater bivalves of the Unio. sp. genre. 


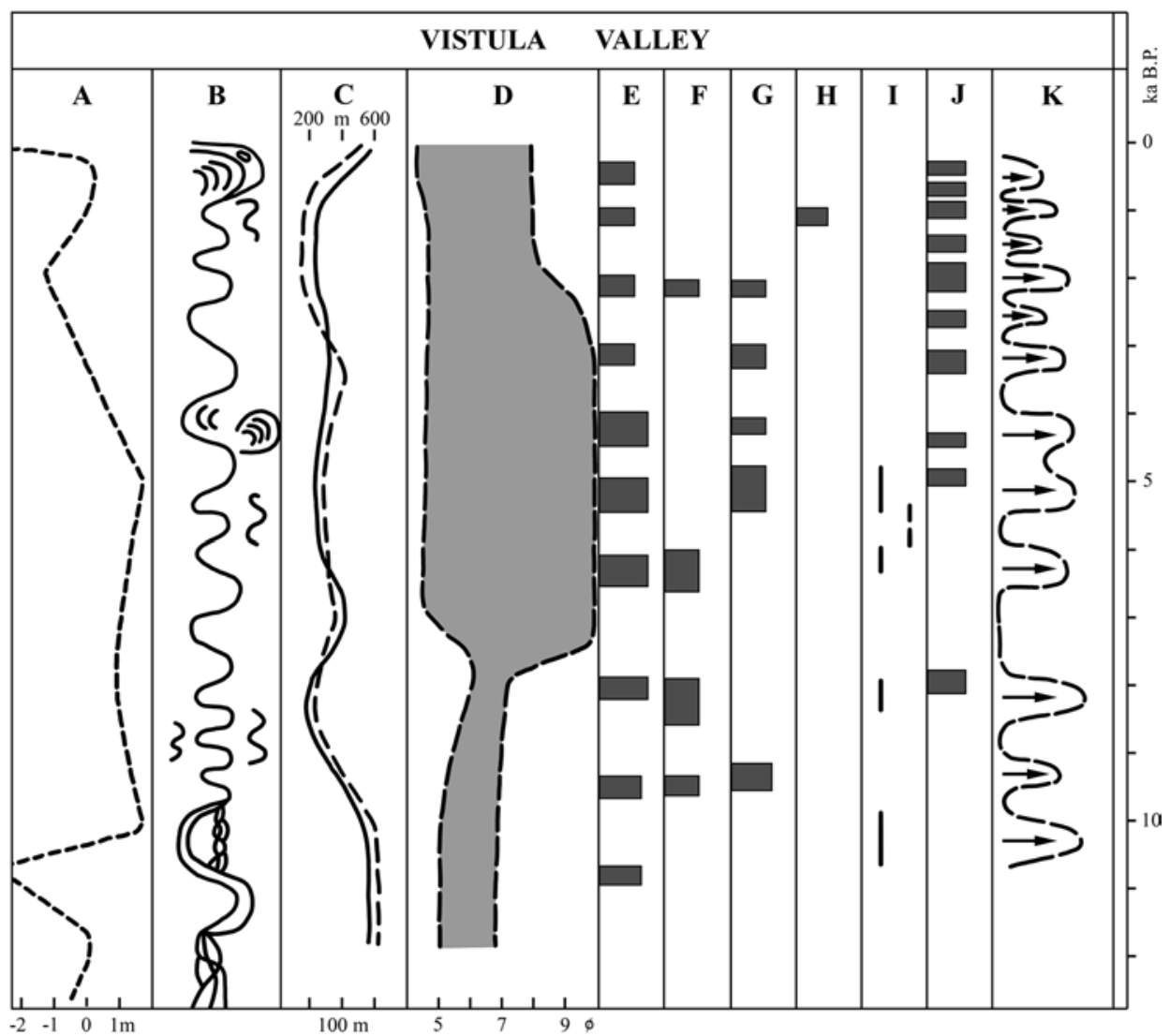

Fig. 3. Reflection of the climatic and anthropogenic changes in both morphology and alluvia of the Vistula river valley near Cracow during the last 13000 years. A - vertical changes of the Vistula river channel, B - channel pattern changes, cut offs and avulsions, C - meander's width (continuous line) and meander's radius (broken line) changes, $\mathrm{D}$ - mean diameter $\mathrm{Mz}$ changes of abandoned channel and overbank deposits, $\mathrm{E}$ - cut offs and channel avulsions, $\mathrm{F}$ - superposition of the overbank sediments and organic deposits, $\mathrm{G}$ - peat initiation, $\mathrm{H}$ - cultural horizons beneath the overbank deposits, I - palaeobotanical data indicating a humid (continuous line) and dry (broken line) climate, J - tree trunks in the alluvia (Krąpiec 1996), $\mathrm{K}$ - phases of the increase in the Vistula activity (Kalicki 2006, ryc. 31)

\section{MATERIALS}

\subsection{Settlement features and artefacts}

During excavations conducted in 1986, four settlement features of the Baden culture were discovered (features: 13a, 15, 18, 19). Traces of their fillings were registered within two ofeight sounding trenches (dimensions: 5 x 5 metres) marked out in the limits of the school to be built (Fig. 4). Within are 343/D features 13 a and 15 were registered and ares 
Table 1. Materials of the Baden culture at site 1 in Zofipole, Kraków district

\begin{tabular}{|c|c|c|c|c|c|c|c|}
\hline $\begin{array}{c}\text { Feature } \\
\text { no }\end{array}$ & $\begin{array}{c}\text { Pottery } \\
\text { fragments }\end{array}$ & $\begin{array}{c}\text { Lithic } \\
\text { artefacts }\end{array}$ & $\begin{array}{c}\text { Animal } \\
\text { bones }\end{array}$ & $\begin{array}{c}\text { Human } \\
\text { bones }\end{array}$ & Shells & Charcoals & Daub \\
\hline $\mathbf{1 3 a}$ & 260 & 12 & 16 & - & 7 & $\mathrm{x}$ & $\mathrm{x}$ \\
\hline $\mathbf{1 5}$ & 181 & 15 & 24 & 5 & 3 & $\mathrm{x}$ & $\mathrm{x}$ \\
\hline $\mathbf{1 8}$ & 83 & 6 & 19 & - & - & - & $\mathrm{x}$ \\
\hline $\mathbf{1 9}$ & 38 & 1 & 1 & - & - & - & $\mathrm{x}$ \\
\hline $\begin{array}{c}\text { Outside } \\
\text { features }\end{array}$ & 58 & - & - & - & - & - & - \\
\hline Total & 620 & 34 & 60 & 5 & 10 & $\mathrm{x}$ & $\mathrm{x}$ \\
\hline
\end{tabular}

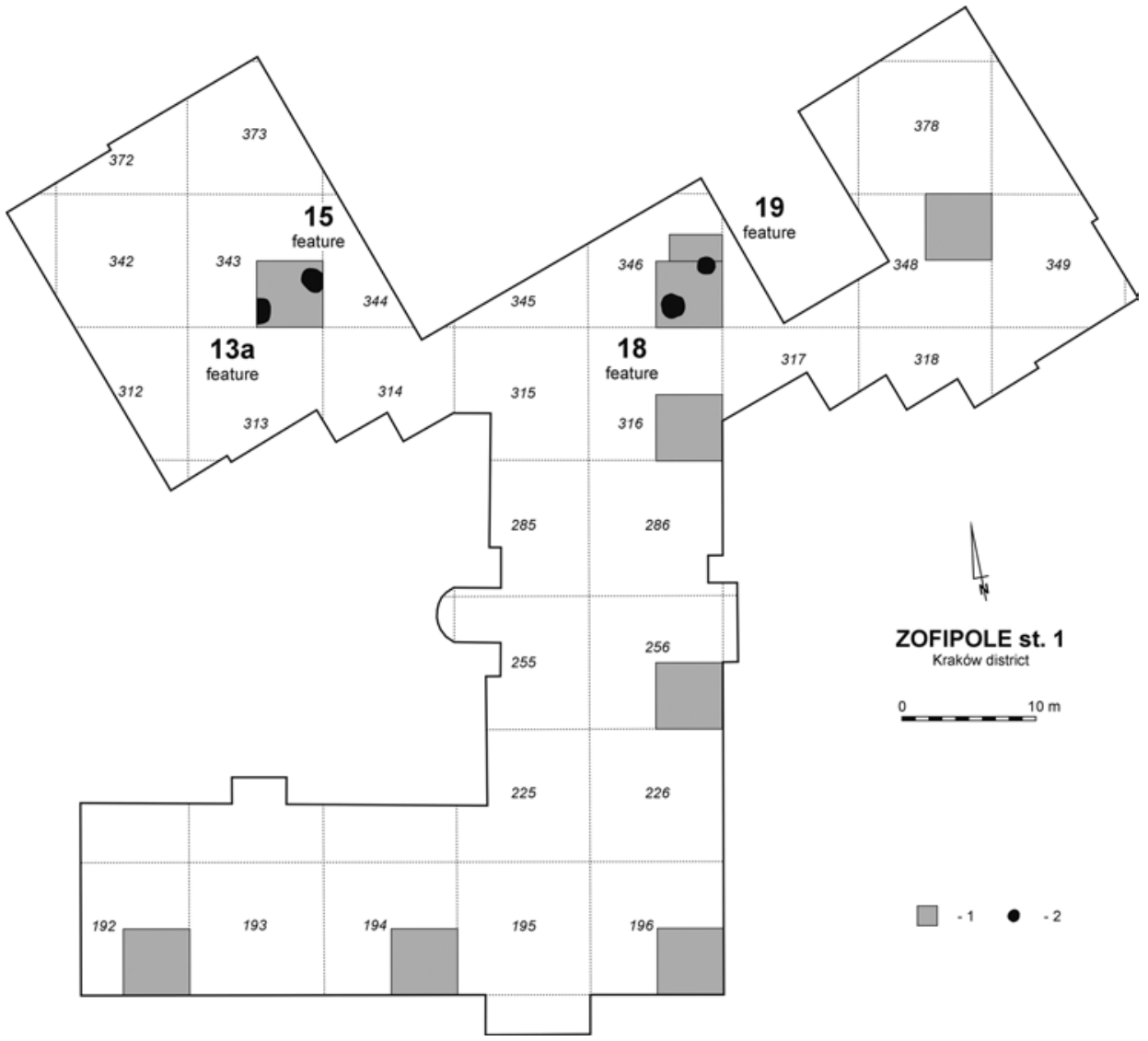

Fig. 4. Zofipole, site 1, Kraków district. Location of excavation units (1) and features of the Baden culture (2) in the background of ares network in the outline of a planned school building. Drawn by A. Zastawny 

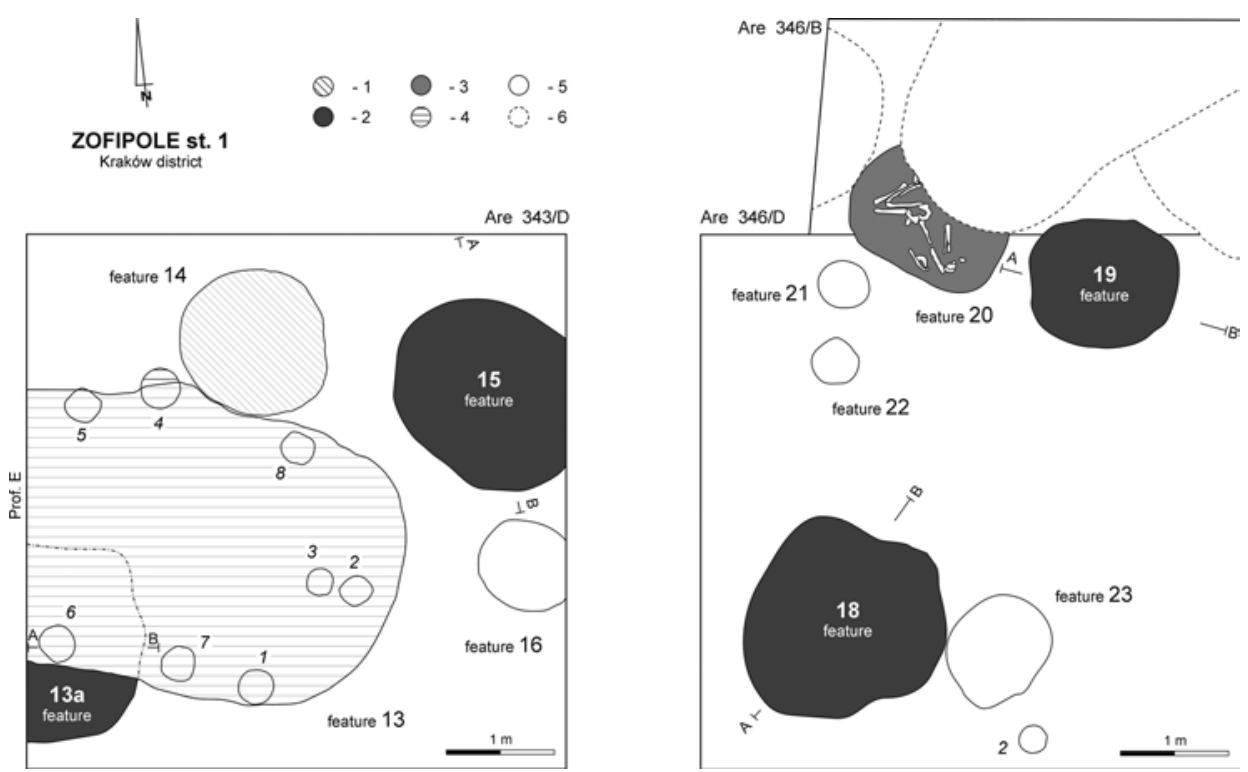

Fig. 5. Zofipole, site 1, Kraków district. Distribution and chronology of features within quarters 343/D, 346/B, 346/D: 1 - Neolithic, 2 - Baden culture, 3 - Lusatian culture, 4- Przeworsk culture, 5 - features of undetermined chronology, 6 - unexcavated features. Drawn by A. Zastawny

346/D and 346/B comprised features 18 and 19 (Fig. 5). The mentioned pits formed two concentrations located 30 metres from one another and divided by a zone that was not subjected to excavation research (Fig. 4). Separate features were located nearby: 3 metres of distance between features 13a and feature 15 and 2.5 metres between features 18 and 19 . In their neighbourhood, other prehistoric features were registered, including: a pit of the Lengyel culture (feature 14), burial of the Lusatian culture (feature 20) and remains of a settlement construction of the Przeworsk culture (feature 13) that partially destroyed a pit of feature 13 a (Fig. 5).

The collection of artefacts of the Baden culture consisted of: 620 fragments of clay vessels, 3 fragments of clay spindle whorls, 34 lithic artefacts, 60 animal bones and teeth, 5 human remains, 10 fragments of shells and several dozens of lumps of daub and remains of burnt wood (Table 1). Fragments of Baden pottery were registered as well in younger features and within natural layers (54 fragments).

Feature 13a (Are 343/D)

Feature 13a is a settlement pit discovered in the south-western part of quarter D, next to the western part of the trench (Fig. 4, 5). Only the western part of the future was excavated with horizontal levels and two cross-sections (cross-section $\mathrm{W}$ and cross-section 
A-B) documented. A ceiling part of the pit was disturbed by the fill of feature 13 that - with a complex of postholes (features 1-8) - remained a settlement construction linked with the Przeworsk culture (Fig. 5). Pit 13a was detectable at the depth of $82 \mathrm{~cm}$ below the level of the ground, under humus layer and glaciolacustrine layer /60 cm deep/ (Fig. 7). Although

\section{Feature 13a}

level120 cm

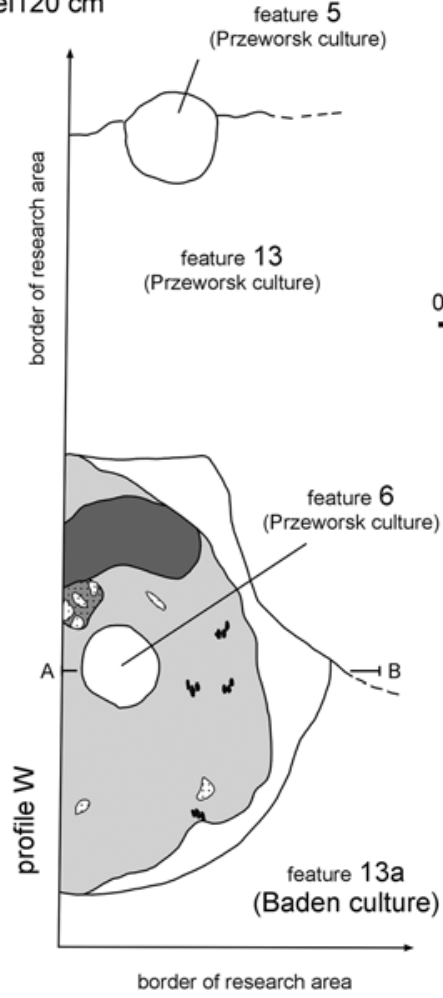

border of research area level $140 \mathrm{~cm} \quad$ feature 5
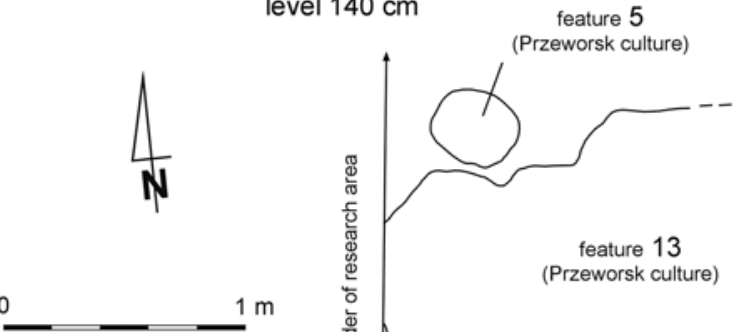

(Przeworsk culture)

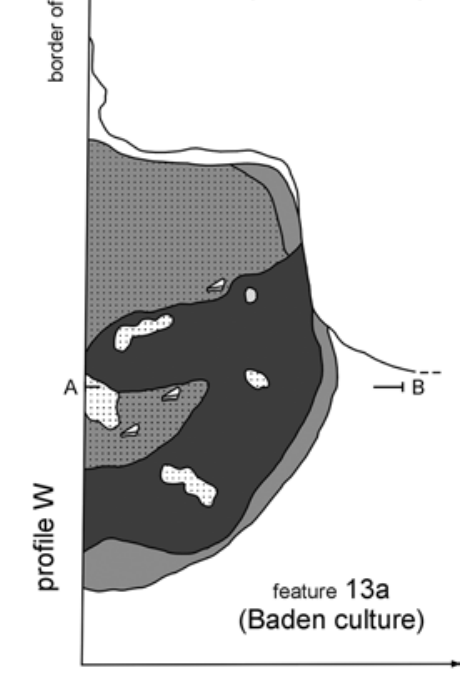

border of research area

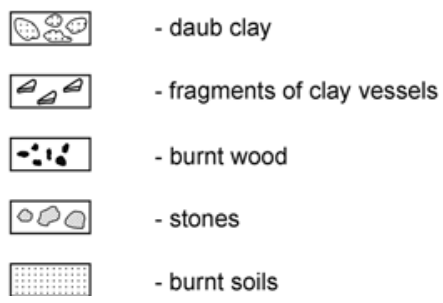

Fig. 6. Zofipole, site 1, Kraków district. The Baden culture: plans of feature 13a (the legend concerns infills of features of the Baden culture). Elaborated by A. Zastawny; drawn by K. Nawrot 


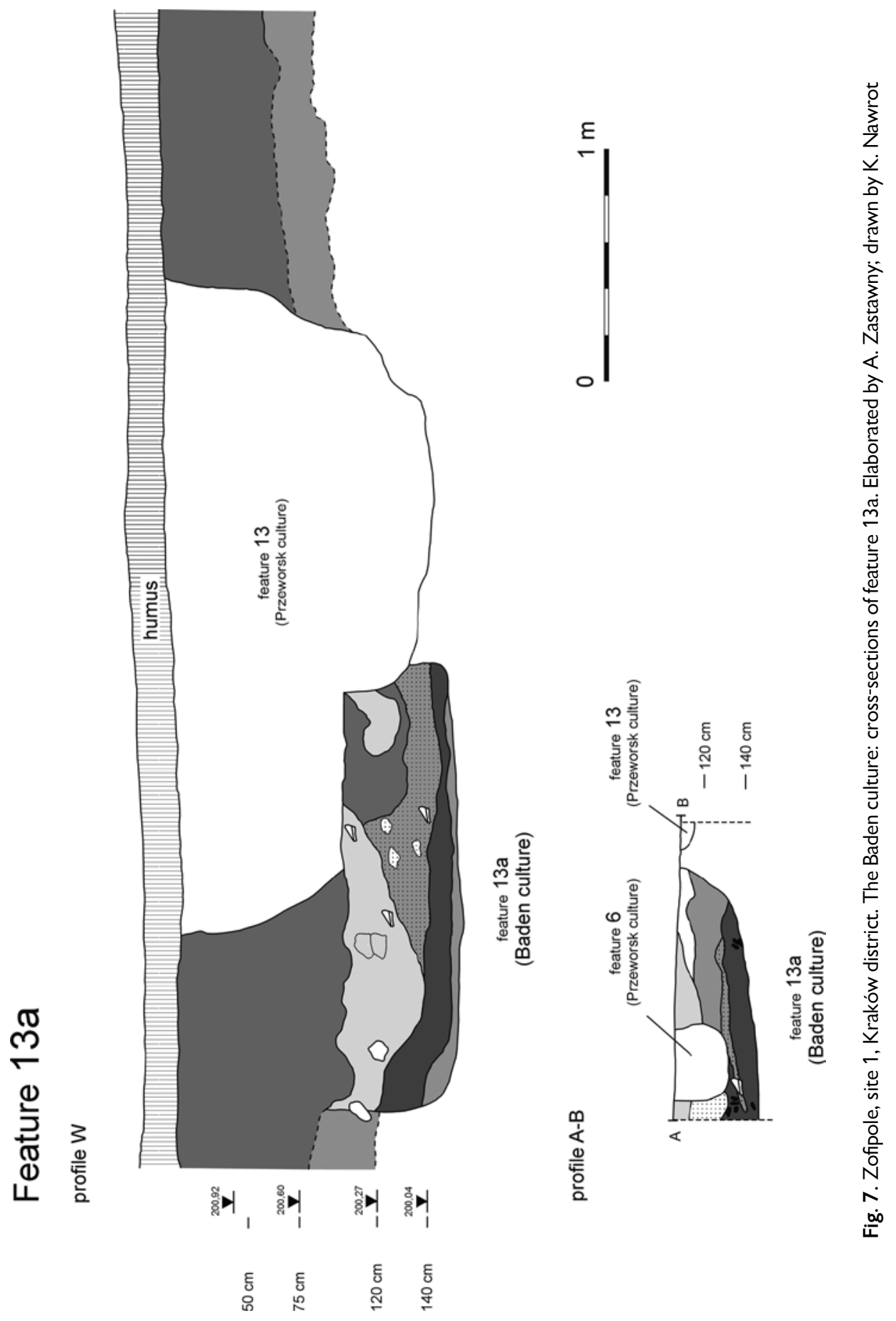


its outline was not complete, we may suppose that the pit was rectangular at the level of its discovery and oval or circular at the bottom (Fig. 6). Its diameter measured up to the trench wall was $186 \mathrm{~cm}$. Its western cross-section (cross-section W) was quadrangular with slightly rounded angles and an equal, almost flat bottom; the maximum depth of its fill was $50 \mathrm{~cm}$ (Fig. 7). In the oblique cross-section A-B grasping its stratigraphic relation with a posthole of the Przeworsk culture (Fig. 6) the feature had a basin-like shape. Within its fill, it was possible to determine several layers. The bottom part was composed of a thin layer of brownish-grey soil and darker brown soil. Both layers were hard and compact with numerous pottery fragments. Over them was a layer with traces of burnt loess (numerous lumps of brittle daub). During exploration at this level $(130-140 \mathrm{~cm})$ a great lump of burnt daub covering a distinct concentration of potsherds was discovered. This layer indicates a border between the functional and destructive parts of the pit. In the ceiling of the feature, two filling layers were registered: yellow and dark brownish. The infill of the pit comprised numerous lumps of daub, charcoals and stones. This feature provided most of the numerous pottery fragments. Due to the animal bone found in its infill we managed to

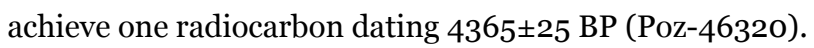

Inventory:

260 pottery fragments, including one complete vessel (Fig. 11), 10 flint artefacts, 1 grindstone made of quartzitic sandstone, 1 grinding stone made of coarse-grained sandstone (Table 3) and crumbs of stone, 16 fragments of animal bones (Table 4, 5), 7 fragments of shell, lumps of daub, charcoal; 3 fragments of pottery dated to the Roman influences period.

\section{Feature 15 (Are 343/D)}

Feature 15 is a settlement pit discovered in the north-eastern part of quarter D at are 343, at the depth of $50 \mathrm{~cm}$ below the level of the ground (Fig. 4-5). A regular, oval outline (dimensions: $196 \times 168 \mathrm{~cm}$ ) was detectable under the humus and glaciolacustrine layer at a depth of $75 \mathrm{~cm}$ (Fig. 8). At this level, researchers intended A-B cross-section. Its vertical projection was trapeziform with a basin-like bottom $225 \mathrm{~cm}$ in diameter. The bottom of the pit was documented at the depth of $210 \mathrm{~cm}$. Within the pit, it was possible to determine three main soil layers of the infill: a dark-brownish basin-like ceiling part, central part of the pit brown-grey in colour - comprising lumps of daub - and a floor with dark-brown soil. Additionally, the bottom part and walls of the pit were bordered with a thin brownyellowish layer (Fig. 8). This feature was not completely explored. The south-eastern part of the pit was located beyond the area of the research (Fig. 5).

Inventory:

181 fragments of pottery (Fig. 12), 15 lithic artefacts (Table 3; Fig. 14:1-2, 4-5), 13 crumbs of stone, 24 fragments of animal bones (Table 4, 5), 5 human bones (2 incisor teeth, a distal fragment of a radius, patella, metapodial bone), 3 fragments of shell, numerous lumps of daub, charcoals; 10 fragments of vessels of the Lengyel culture (Sam- 


\section{Feature 15}

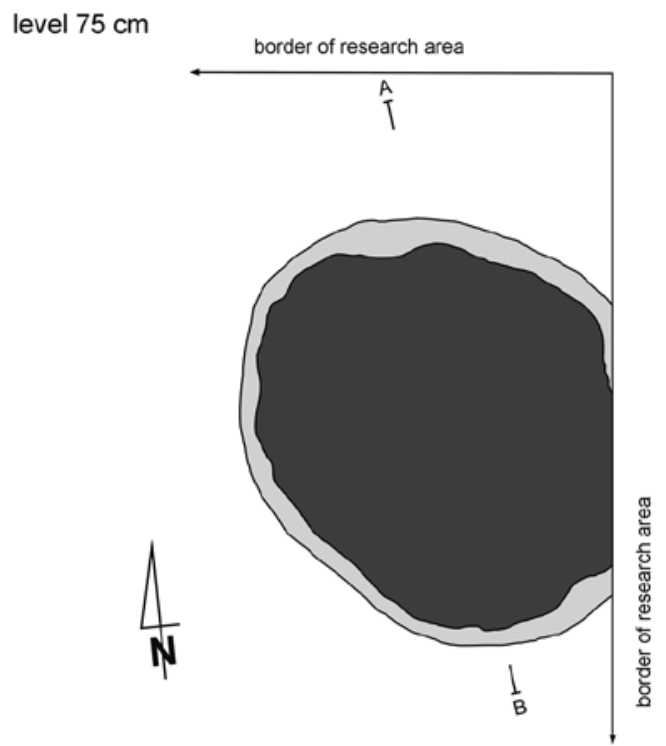

profile A-B

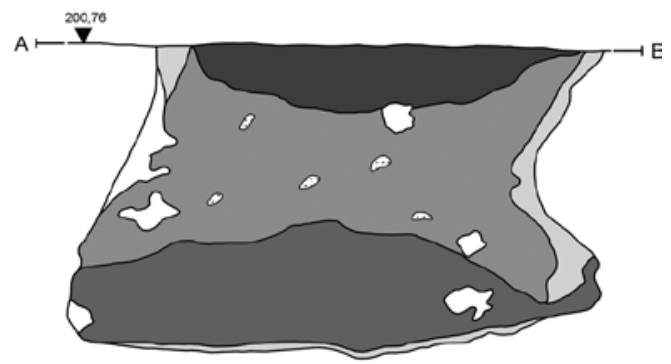

0 $1 \mathrm{~m}$

Fig. 8. Zofipole, site 1, Kraków district. The Baden culture: plan and cross-section of feature 15. Elaborated by A. Zastawny; drawn by K. Nawrot

borzec-Opatów group); 4 fragments of vessels dated to the Roman influences period; 1 modern potsherd.

Feature 18 (Are 346/D)

Feature 18 is a shallow settlement pit $(193 \times 180 \mathrm{~cm})$, irregularly circular in its vertical cross-section, discovered in the south-western part of quarter D at are 346, at the depth of 
Feature 18

level $25 \mathrm{~cm}$

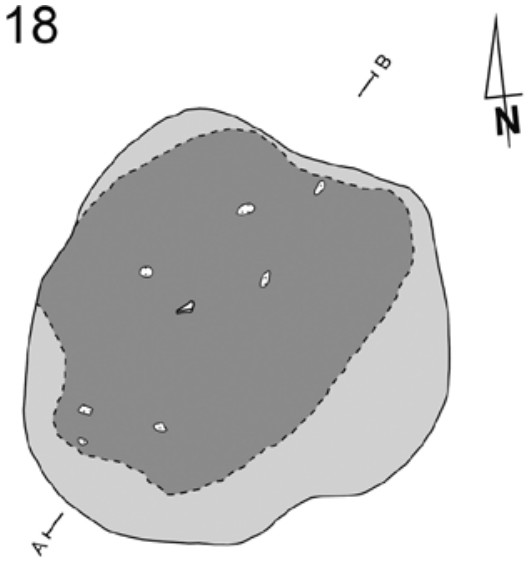

level $65 \mathrm{~cm}$

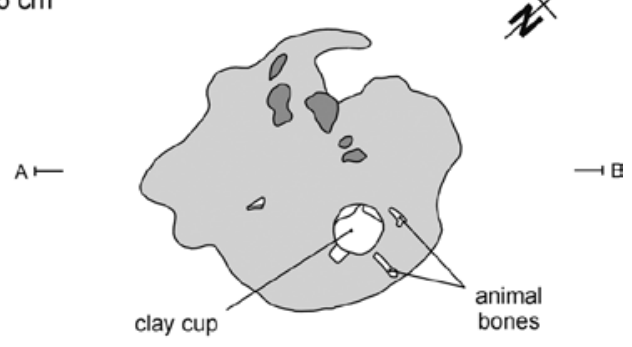

profile A-B
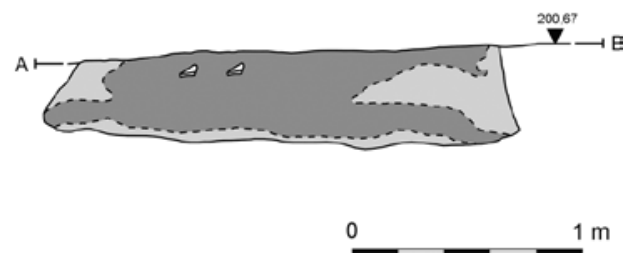

Fig. 9. Zofipole, site 1, Kraków district. The Baden culture: plans and cross-section of feature 18.

Elaborated by A. Zastawny; drawn by K. Nawrot

$25 \mathrm{~cm}$ below the upper surface of the humus (Fig. 4, 5). Only the bottom part of the pit preserved (43 cm deep), trapeziform in a cross-section (cross-section A-B) and slightly vaulted at the bottom $/ 68 \mathrm{~cm}$ below the level of the ground/ (Fig. 9). At the depth of $65 \mathrm{~cm}$, explorers registered a fading, "blotchy" infill of the bottom of the pit with a complete clay cup decorated with a band-shaped handle reaching below the rim of the vessel and a belly ornamented with zones of grooves and holes ornamentation (Fig. 2). Animal bones were 
foundin thedirect vicinity of the vessel and it was possible to determine a radiocarbon dating for one of them: $4345 \pm 35$ BP (Poz-46321). The infill of the pit is composed of the main soil layer (brown-grey) and yellow-brown soil forming cuneiform side incisions which is typical for trapeziform pits - and a thin bottom layer (Fig. 9).

Inventory:

83 fragments of pottery, including 1 complete vessel (Fig. 2; Fig. 12: 1-9), 6 flintartefacts (Table 3), 7 crumbs of stone, 19 animal bones (Table 4, 5), lumps of daub; 1 fragment of a modern vessel.

Feature 19 (Are 346/B, D)

Feature 19 is a bottom part of a small, one-layered pit. Its vertical cross-section was oval but resembling a rectangle $(135 \times 118 \mathrm{~cm})$; the bottom part was unequal and asymmetrical (Fig. 10). The feature was distinguished as ,a concentration of potsherds at the bottom of a pit" at the depth of $25 \mathrm{~cm}$ below the level of the ground in the north-eastern part of are 346 at the border between two quarters $-C$ and D (Fig. 5). The vast majority of potsherds derived from a large amphora ornamented with decoration of relief and grooves

\section{Feature 19}

level $25 \mathrm{~cm}$

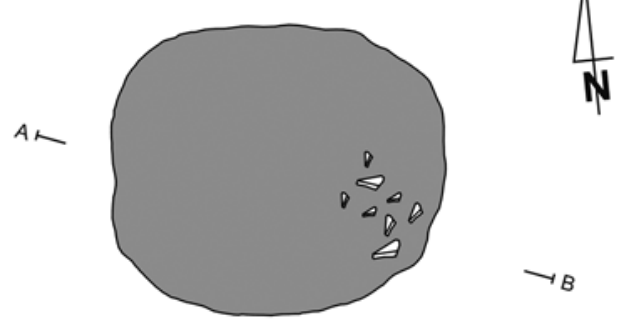

profile A-B
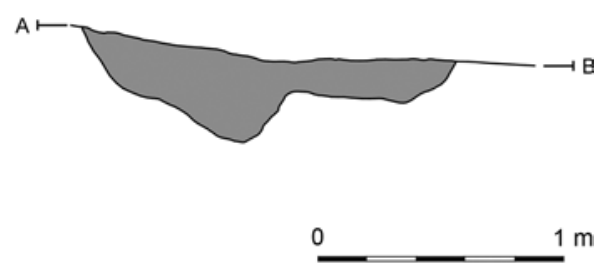

\footnotetext{
$\begin{array}{ll}80 & \text { fragments } \\ & \text { of clay amphorae }\end{array}$
}

Fig. 10. Zofipole, site 1, Kraków district. The Baden culture: plan and cross-section of feature 19. Elaborated by A. Zastawny; drawn by K. Nawrot 
(Fig. 13: 1), discovered in the form of a concentration of crushed potsherds nearby the eastern edge of the pit (Fig. 10). With this feature, we should as well join a hemispherical, unornamented cup with a damaged handle, registered over the top of the pit in the ploughland layer (Fig. 13: 5).

Inventory:

38 fragments of pottery - the majority of them derived from the large amphora (Fig. 13: 1-4), 1 flake from an axe made of Jurassic flint with traces of polishing (Table 3, fig. 14:3), 1 crumb of stone, 1 animal bone (Table 4, 5), lumps of daub.

\subsection{Materials of the Baden culture registered beyond its features}

The far from numerous artefacts of the Baden culture were registered beyond features of the Baden culture - in total: 57 fragments and one complete vessel. The majority of them were found as secondary deposits (35 fragments) within younger pits linked with settlement dated to the Roman influences period - most of all in the fill of a settlement construction of the Przeworsk culture (feature 13 - 27 fragments) that damaged the ceiling of the facility 13a (are 343/D). One of the most interesting discoveries is the ornamented, hemispherical cup with a damaged band-shaped handle (Fig. 13: 5) discovered at are 346/ $\mathrm{D}$ over the top of feature 19. It is very possible that this vessel derived from its fill. The next 11 fragments of vessels dated to the Baden culture were registered in the vicinity of features 19 and 18. Apart from mentioned materials derived from two sounding trenches, pottery fragments linked with the Baden culture were found within four other trenches located in the area of the research: ares 348, 256, 192, 196 (Fig. 4). They are separated finds (2-7 fragments) excavated during exploration features dated to younger periods (features 2, 3b, 4, $5,11)$ and natural soil layers.

\section{ANALYSIS OF MATERIALS}

\subsection{Settlement pits}

Two of the four features explored in Zofipole are trapeziform pits - the most typical of the Baden culture in Lesser Poland semi-subterranean settlement constructions (Godłowska 1968; 1976; Kozłowski 1968; Sochacki 1988; Bober 1993, 1994; 1998). Features 15 and 18 had similar, oval outlines and dimensions at the level of discovery and a typical, trapeziform bottom shape (Fig. 8, 9). Their depths were different (135 cm - feature 15 and $43 \mathrm{~cm}$ - feature 18). They differed as well as in terms of the number and type of artefacts. Pit 15 comprised numerous but very abraded pottery fragments (181 fragments). It included the most numerous collection of potsherds deriving from pottery for 
salt production (Table 2), all of the human bones discovered at the site and also the most numerous assemblages of lithic artefacts and animal bones (Table 1). All these materials landed in this pit during its multi-stage destruction. Feature 18 included fewer pottery fragments (83) but at the bottom of this pit a complete cup was found. It is ornamented with zones of grooves and holes and a band-shaped handle (Fig. 2). Remaining materials mostly animal bones - were found in the infill. Both pits were used for various economic activities - originally they most probably had served as storage pits, then they were used as waste pits - particularly a deep, layered pit 15 .

Two remaining features - 13a and 19 - are even more interesting and differ in their shape and destination. The fragmentarily researched feature 13a (Fig. 5) with a rectangular outline at the level of discovery and oval or circular in the bottom part (Fig. 6) distinctly stands out. At one of documented cross-sections (cross-section W) the pit resembles a regular quadrilateral with slightly rounded angles and an equal, almost flat bottom. The thickness of the infill did not exceed $50 \mathrm{~cm}$ and its maximum width $-186 \mathrm{~cm}$ (Fig. 7). The described pit may be treated as the remains of a not very deep, dwelling structure, regular in outline and with a rectangular shape and dimensions of 2.5-3.0 x 2.0 metres. Additional presumptions to such interpretations are traces of wall destruction (?) in the form of a layer of burnt loess and lumps of daub laid over the bottom, functional part of the pit (Fig. 7). This thesis is proved as well by the registration in this feature of the most numerous (26o fragments) and best preserved fragments of pottery and other clay artefacts (spindle whorls). Among traces of settlement numerous at Baden sites, the least represented and, at the same time, the most troublesome in interpretation are constructions linked with a dwelling function (examples and opinions, see: Sochacki 1971; Rook 1971; Rydlewski, Valde-Nowak 1980; Sochacki 1988; Balcer 2012). The limited data on shallow pithouses compared with the valuable results of spatial analysis of settlement in KrakówPleszów 17-20 by E. Rook reinforced the basis for the thesis that predominating, in not the only, form of settlement features were structures characterized by an archaeologically undetectable construction (log frame structure) surrounded by utility pits (Rook 1971). The dwelling function of feature 13a should be treated as hypothetical due to a fact that its recognition was only fragmentary. Admittedly, in published sources researching settlement of the Baden culture in Lesser Poland there are no analogies for the described construction.

Feature 19 is the smallest among the pits researched (Fig. 10). Its features link it with a different function than economic or dwelling. Small dimensions, an irregular bottom at the depth of $20-40 \mathrm{~cm}$, outline resembling quadrilateral, one-layered filling and the concentration of artefacts near the edge of the pit may suggest that it served as a place for the burial or for the deposit of vessels. The vast majority of potsherds discovered here derived from one vessel - a large amphora ornamented with vertical grooves and a horizontal plastically formed band decorated with finger impressions (Fig. 13: 1). The location of this amphora near the western border of the facility and - most of all - the form of the vessel, 
typical of human burials of the Baden culture in Lesser Poland (two graves from KrakówZesławice 21 equipped with amphorae; cf. Zastawny 2009), could have indicated the burial character of this pit (with an unpreserved skeleton). The fact that that no bones were found within the pit cannot be explainedby, for example, unfavourable soil conditions. At a distance of $50 \mathrm{~cm}$ from feature 19, a skeleton burial of the Lusatian culture was found (feature 20, Fig. 5). Taking this into account, we incline to the interpretation that feature 19 was a deposit of vessels. Apart from the mentioned amphora, another finding should be joined with this feature - a hemispherical cup with a handle broken off (Fig. 13: 5), discovered just above the ceiling of this pit. The surroundings of the pit had been subjected to intense post-depositional processes noticeable due to disturbances of its top, the squashed fragments of the amphora and the presence of several dozen fragments of other forms of vessels in the fillof the feature. Deposits of ceramics are common in the Baden culture, including also areas of Lesser Poland, and their dubious interpretation does not exclude ascribing them to the category of symbolic burials (for ex. Igołomia, Żaki 1949).

\subsection{Vessel type ceramics}

The research conducted at site 1 in Zofipole revealed 620 fragments of clay vessels of the Baden culture (Table 2). The vast majority of potsherds were yielded within fills of four settlement features (562 fragments),the remaining fragments were found as secondary deposits in chronologically younger features and layers of natural origin. A predominant part of potsherds (393 fragments) derived from six typological forms: amphorae, cups, bowls, beakers, pots and pots with wide mouths (Fig. 11-13). Analyses of ornamentation and technical treatments led to distinguishing four basic groups of decoration types and surface treatment (Table 2). The following were distinguished: grooved ornamentation (grooves and flutings), impressed ornamentation (holes and fingertip indentations), plastic decoration (bands and knobs) and smearing and coarsening of outer walls of pots with wide mouths. The research analysing genres of admixtures to ceramic mass made possible the indication of technological preferences and relations between admixtures and types or functions of vessels.

The best represented types of vessels are pots with a wide mouth characterized by bag-shaped or S-shaped profile (223 fragments). They have been preserved almost exclusively as fragments of bellies decorated with a characteristic smearing of the outer surfaces of walls - noticeable as vertical or oblique, irregular lines (Fig. 12: 5; 13: 4). Only one fragment of a mouth has been preserved - it is decorated with ornamentation in the form of horizontal, by-the-lip band with fingertips impressions very typical for this group of vessels (Fig. 13: 7). The well-preserved, large fragments of bellies indicate, as in the case of inventories of the Baden culture from other sites, that they are fragments of large storage vessels or kitchen ware (cf. Zastawny 2011, Fig. 11). They were produced with the use of very diversified admixtures, including: fireclay, ceramic rubble 

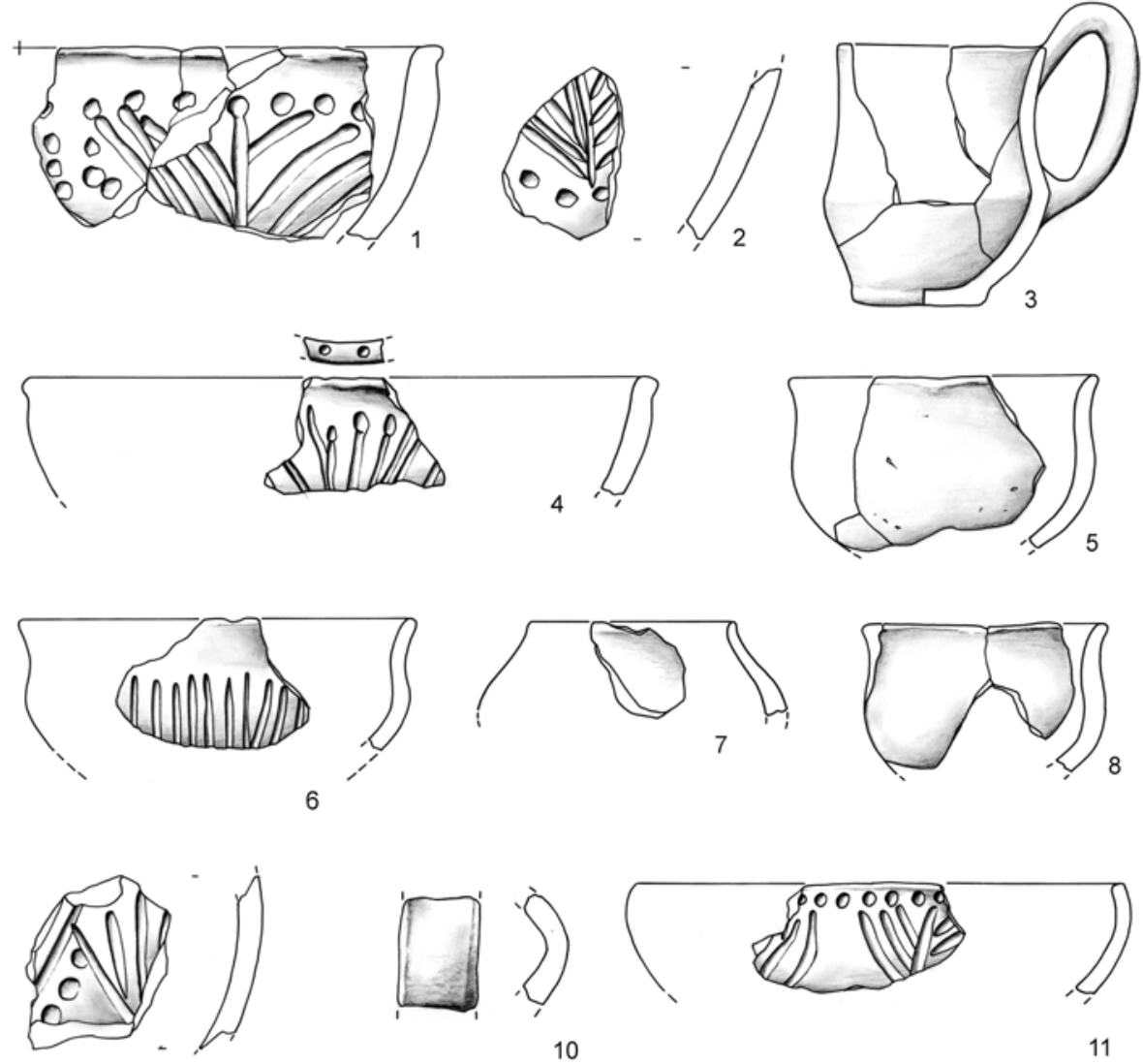

10

9

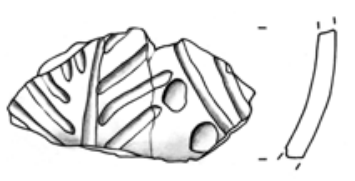

12

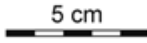

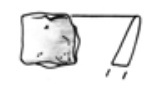

16

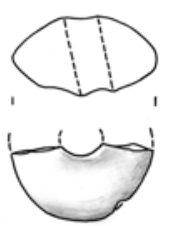

13

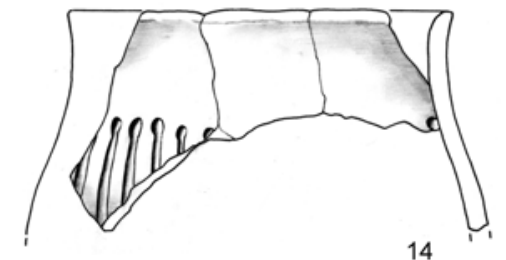

14

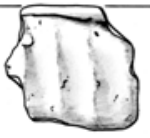

Fig. 11. Zofipole, site 1, Kraków district. Selection of pottery materials of the Baden culture from feature 13a. Drawn by A. Zastawny 

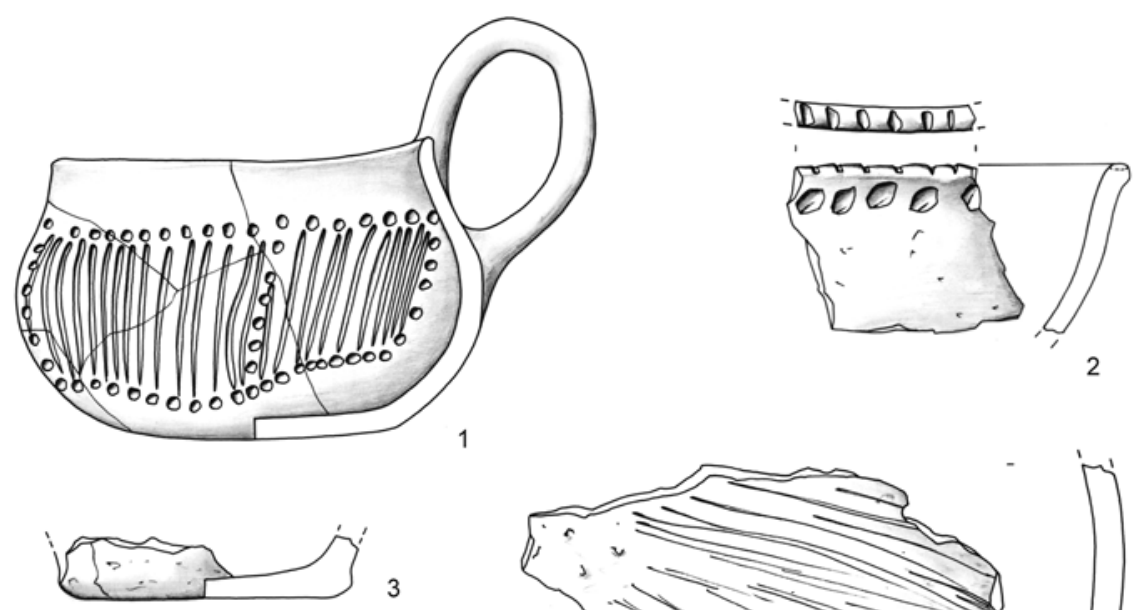

3
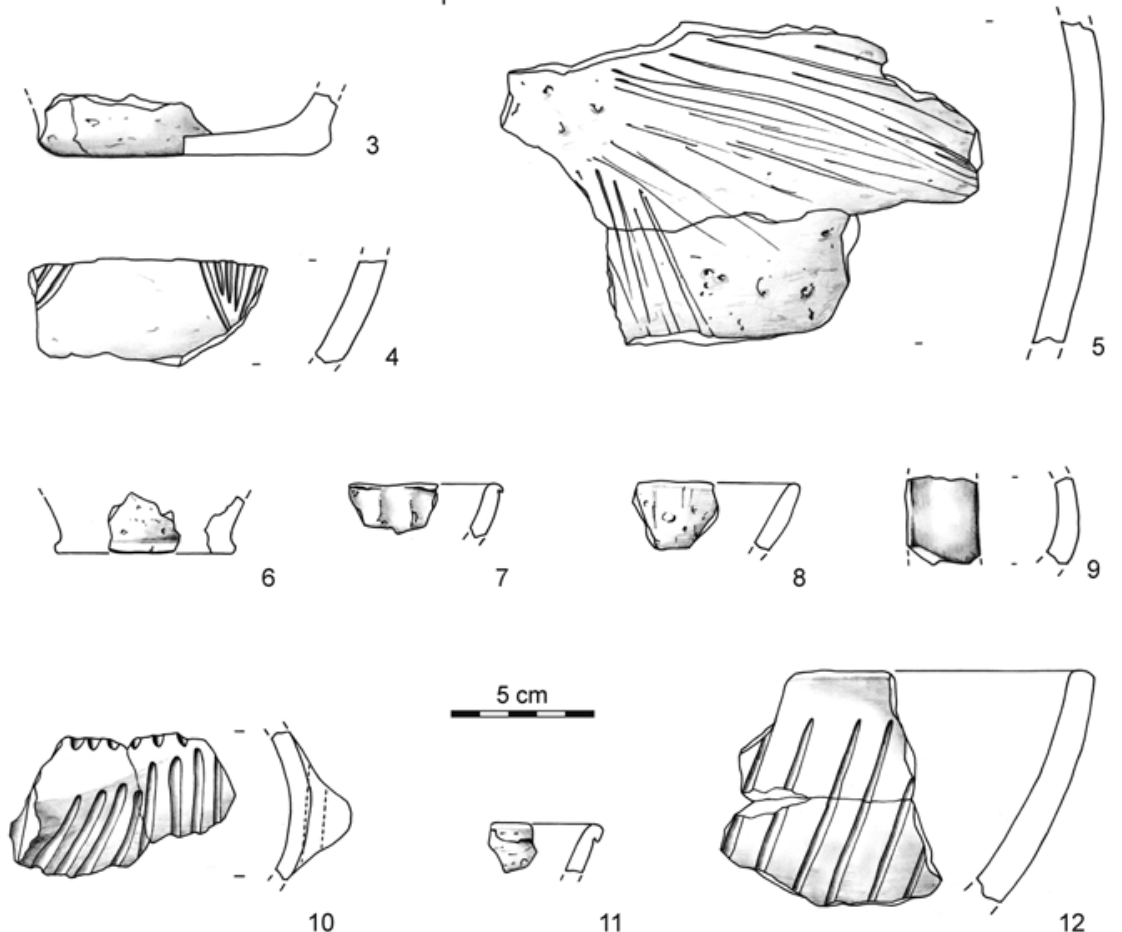

11

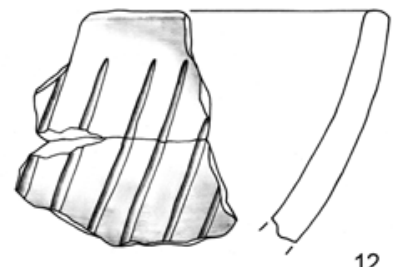

12

Fig. 12. Zofipole, site 1, Kraków district. Selection of pottery materials of the Baden culture from feature 18 (1-9) and feature 15 (10-12). Drawn by A. Zastawny 


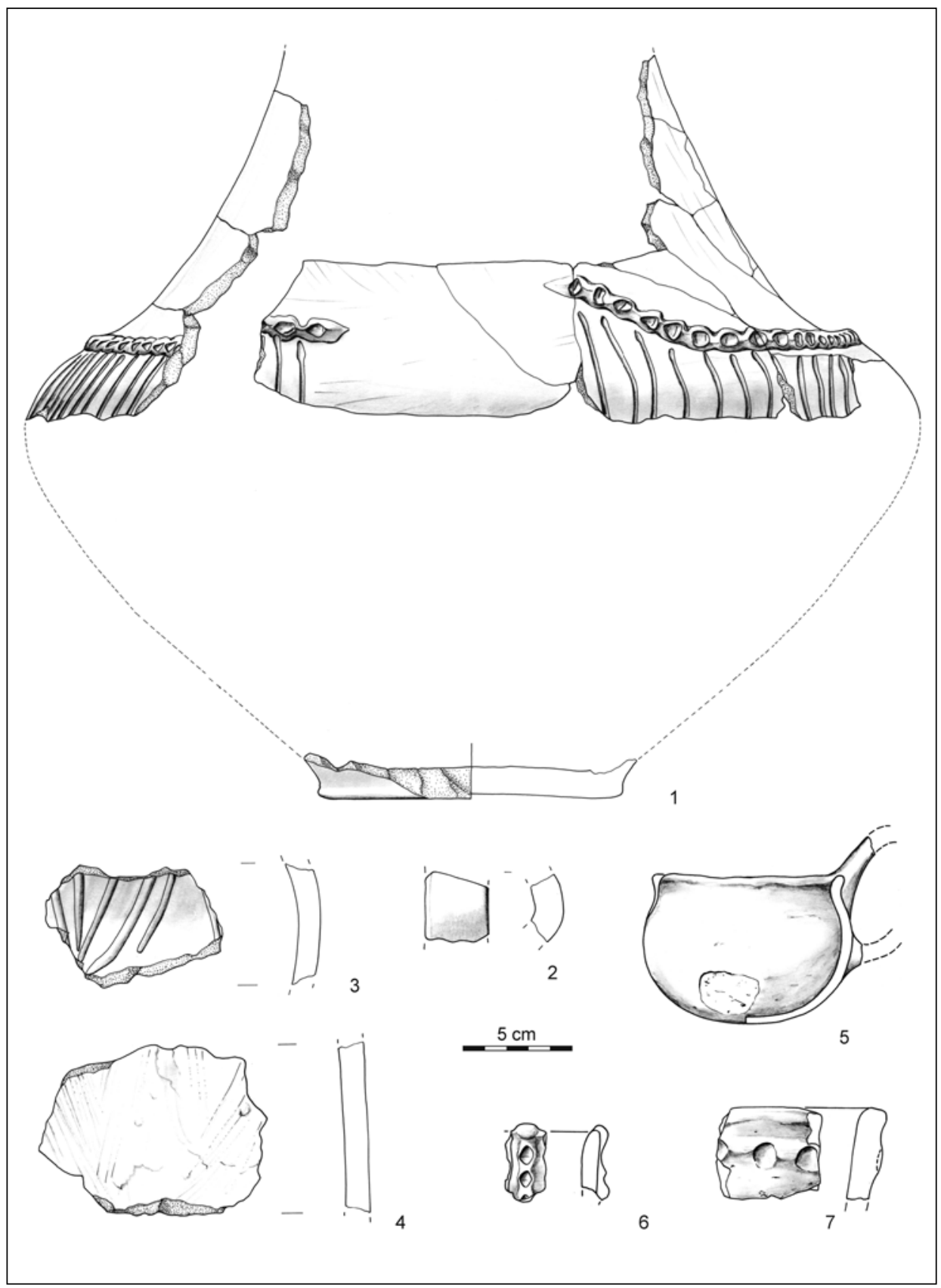

Fig. 13. Zofipole, site 1, Kraków district. Selection of pottery materials of the Baden culture from feature 19 (1-4), materials discovered over its ceiling (5) and from feature 11 (6) and feature 5 (7). Drawn by B. Grabowska, A. Zastawny 


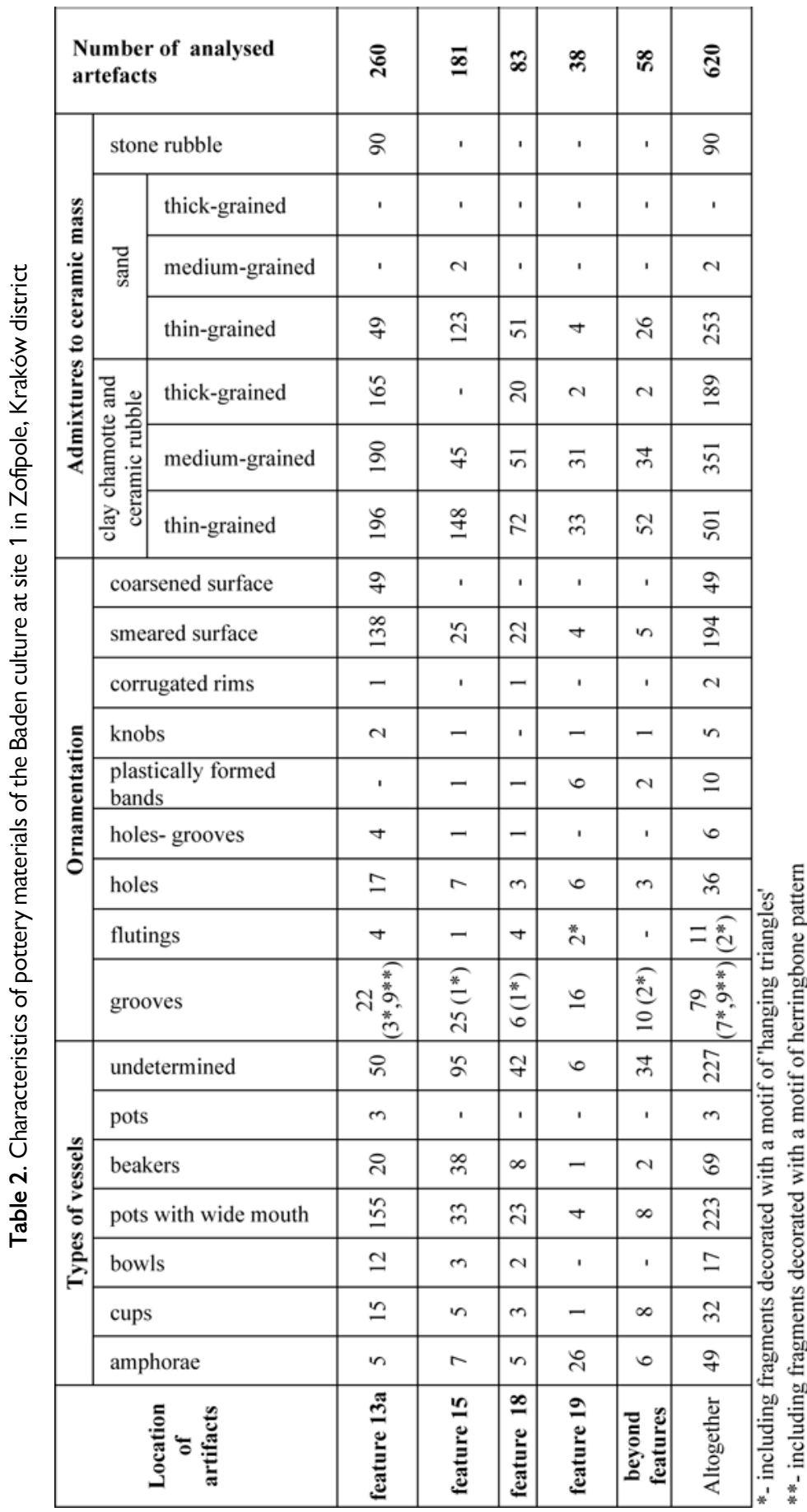


and well-granulated sand. The presence of ceramic rubble as the admixture has been recognized only at this separated site up to now.

Among the vessels classified as pots, several specimens represent vessels of a pot type but of better quality, ornamented with decorations typical of bowls and amphorae. A large fragment of such a form with walls decorated with horizontal grooves was discovered in feature 13a (Fig. 11: 14).

The ceramic materials of the Baden culture in Zofipole are exceptional due to the assemblage of very fine, thin-walled potsherds characterized by forms and technology different than in case of remaining fragments of vessels at this site. The differences concern both their very intensely fired walls (brick-red and orange colour with whitish coating covering outer surfaces) and the conical (goblet-like) shapes of vessels (Fig. 11: 17). Other characteristic features are traces of horizontal smearing decorated with fingertips on outer surfaces of vessels and presence of exclusively thin-grained sand within ceramic mass (Fig. 11: 17; 12: 7). This characteristics of the pottery lets us define it as being usedfor salt production (Rook 1971; Zastawny 2000; 2014). Fragments of pottery of such type (69 fragments) were registered in each of excavated features of the Baden culture at site in Zofipole (the most numerous collection was found in feature 15). In this category, fragments of bellies prevail. The most characteristic are small, distinctly marked bottoms (Fig. 12: 8) and mouths with slightly thickened and splayed rims (Fig. 11: 17; 12: 7, 11). These forms are reconstructed as $20 \mathrm{~cm}$ high, conical vessels with a splayed rim (diameter of 22-25 cm) and narrow bottom $(6-8 \mathrm{~cm})$. On this account they are very similar to the salt beakers known from settlements of the Baden culture in Kraków-Pleszów 17-20 (Rook 1971, 233) and Kokotów 13 (Zastawny 2014, Tables: III: j, IV: c). The discovery of pottery for salt production at the discussed site is surprising. Certainly, it indicates that this site was one of the areas of the Baden culture involved in salt production (cf. Zastawny 2000).

At the site in Zofipole, less represented vessels are amphorae, bowls and cups -usually the most typical forms at settlements of the Baden culture. The best preserved amphora was found in feature 19 (Fig. 13: 1). It is not complete - it lacks the upper part of a neck with a rim and handle and the lower part of a belly. On the basis of thediameter of the belly and bottom, it is possible to reconstruct the height of the vessel (more than $35 \mathrm{~cm}$ ) and its maximum wideness $(41 \mathrm{~cm})$. It was a large amphora ornamented with wide, horizontal grooves separated from the neck with a horizontal plastically formed band decorated with fingertips impressions (cf. Zastawny 2011, Fig. 10). Remaining fragments of vessels are small parts of bellies ornamented with grooves and flutings, sometimes with fragmentarily preserved handles placed on the maximum protrusion of a belly (Fig. 12: 10). In ceramic mass, clay chamotte and thin-grained and medium-grained ceramic rubble prevail.

Except for a big hemispherical cup abundantly decorated with grooves and holes (Fig. $2 ; 12: 1$ ) registered at the bottom of feature 18 , remaining vessels of this category as well as their fragments were devoid of ornamentation. It is untypical of the Baden culture where cups decorated with various motifs and techniques are usually the most numerous vessels 
at sites. Cups from Zofipole (32 fragments in total) were discovered mainly in a fill of feature 13a (Table 2; Fig. 11). They derive from small forms (by-the-bottom parts unpreserved up to date), with S-shaped profile and a diameter of a mouth up to $11 \mathrm{~cm}$ (Fig. 11: 5, 8). Band-shaped handles were preserved only as broken fragments (Fig. 11: 10; 12: 9; 13: 2). One of the undecorated cups is noteworthy on account of its untypical form, resembling a slender jug with a distinctly separated and slightly splayed outwards neck and a bandshaped handle (Fig. 11: 3). There are no analogies for this vessel in materials known from Lesser Poland - in contrast to Carpathian assemblages where this form of a high jug is one of the most common types of vessels (cf. for ex.: Bondár, Raczky 2009; Horváth 2012). An already mentioned cup from feature 18 precisely fits in Lesser Poland standards - it is squat, with a distinctly marked bottom and decorated with ornamentation of grooves concentrated in groups surrounded with circular fingertips impressions. Similar specimens are known from Baden settlements in Kraków-Zesławice 21 (Godłowska 1968), KrakówMogiła 53, 55 (Godłowska 1976; Bober 1993), Kraków-Branice 76 (Godłowska 1986). An almost completely preserved (without a part of a band-shaped handle) hemispherical cup with unmarked bottom was also discovered over the ceiling of feature 19 (Fig. 13: 5). This specimen was unornamented as well.

The least frequent group of vessels are bowls, represented by barely 17 fragments. As in the case of cups, they derive mainly from feature 13a. Several fragments were registered as well in features 15 and 18 . Although this collection is not numerous, it is very diversified on account of its typology and ornamentation. We can distinguish three basic types of bowls: hemispherical bowls with a straight or slightly splayed outwards mouth (Fig. 12: 12; 11: 4), bowls with an inverted mouth (Fig. 11: 11) and bowls with a S-shaped profile (Fig. 11: 6; 12: 12). Each of the fragments are decoratedand the motifs and forms are diversified: straight and oblique grooves (Fig. 11: 6; 12: 12), rows of fingertips impressions below the edge (Fig. 12: 2), corrugated edges (Fig. 11: 4; 12: 2) and arrangements of grooves or combinations of grooves and fingertips impressions in typical of the Baden culture motives of so-called 'hanging triangles' (Fig. 11: 4; 12: 4) and herringbone patterns (Fig. 11: 1-2, 9, 11-12). The second one is particularly characteristic for materials in Zofipole (Table 2). The most numerous analogies for this decoration are known from the largest settlement of the Baden culture in Lesser Poland - Kraków-Pleszów 17-20 (Rook 1971).

Except for some uncharacteristic and unornamented fragments of 3 various clay spindle whorls, any other clay artefacts linked with the Baden culture were not found at the site. All fragments of spindle whorls were discovered in feature 13a (Fig. 11: 13).

\subsection{Lithic artefacts}

The lithic assemblage of the Baden culture yielded during excavations is composed of only 34 specimens. The most numerous are flakes, blades and chunks with traces of single scars (Table 3). Additionally, the collection includes several retouched tools and partially 
Table 3. Characteristics of lithic materials of the Baden culture at site 1 in Zofipole, Kraków district

\begin{tabular}{|c|c|c|c|c|c|}
\hline $\begin{array}{c}\text { Feature } \\
\text { no }\end{array}$ & Inv. no & Depth & Number and type & Raw material & Comments \\
\hline \multirow{5}{*}{ 13a } & $155 / 86$ & profile & $\begin{array}{l}3 \text { chunks with scars } \\
1 \text { grindstone }\end{array}$ & $\begin{array}{l}\text { Jurassic erratic flint } \\
\text { sandstone }\end{array}$ & \\
\hline & $154 / 86$ & $\begin{array}{l}140 \mathrm{~cm} \\
\text { (bottom) }\end{array}$ & $\begin{array}{l}1 \text { chunks with scar } \\
1 \text { flake } \\
1 \text { blade (distal part) } \\
1 \text { grinder }\end{array}$ & $\begin{array}{l}\text { Jurassic erratic flint } \\
\text { Jurassic flint } \\
\text { Jurassic flint } \\
\text { sandstone }\end{array}$ & \\
\hline & $153 / 86$ & $\begin{array}{l}140 \mathrm{~cm} \\
\text { (bottom) }\end{array}$ & 1 flake & Jurassic flint & \\
\hline & $151 / 86$ & $120-140 \mathrm{~cm}$ & 1 retouched chunk & Jurassic erratic flint & \\
\hline & $152 / 86$ & $120-140 \mathrm{~cm}$ & 2 chunks & burnt flint & natural \\
\hline \multirow{6}{*}{15} & $165 / 86$ & $75-95 \mathrm{~cm}$ & $\begin{array}{l}1 \text { truncated blade } \\
1 \text { blade (mesial part) }\end{array}$ & $\begin{array}{l}\text { Jurassic flint } \\
\text { Jurassic flint }\end{array}$ & Fig. 14: 4 \\
\hline & $166 / 86$ & $75-95 \mathrm{~cm}$ & $\begin{array}{l}1 \text { chip } \\
1 \text { chunk }\end{array}$ & $\begin{array}{l}\text { Jurassic flint } \\
\text { burnt flint }\end{array}$ & \\
\hline & $167 / 86$ & $95-115 \mathrm{~cm}$ & $\begin{array}{l}1 \text { combined tool endscraper }+ \\
\text { dihedral burin } \\
1 \text { initial endscraper on a flake } \\
1 \text { retouched blade with marginal } \\
\text { retouch } \\
1 \text { flake } \\
1 \text { chunk }\end{array}$ & $\begin{array}{l}\text { Jurassic flint } \\
\text { Jurassic flint } \\
\text { Jurassic flint } \\
\\
\text { Jurassic flint } \\
\text { Jurassic erratic flint }\end{array}$ & $\begin{array}{l}\text { Fig. 14: } 1 \\
\text { Fig. 14: } 5 \\
\text { natural }\end{array}$ \\
\hline & $169 / 86$ & $120-140 \mathrm{~cm}$ & 1 flake from polished axe & Jurassic flint & Fig. 14: 2 \\
\hline & $170 / 86$ & $140-160 \mathrm{~cm}$ & $\begin{array}{l}1 \text { flake from polished axe } \\
1 \text { blade } \\
1 \text { flake } \\
1 \text { flake }\end{array}$ & $\begin{array}{l}\text { Jurassic flint } \\
\text { Jurassic flint } \\
\text { Jurassic flint } \\
\text { Jurassic erratic flint }\end{array}$ & \\
\hline & $171 / 86$ & $160-190 \mathrm{~cm}$ & 1 flake & Jurassic flint & \\
\hline \multirow{3}{*}{18} & $177 / 86$ & $25-45 \mathrm{~cm}$ & $\begin{array}{l}1 \text { blade (proximal part) } \\
1 \text { flake } \\
1 \text { chunk }\end{array}$ & $\begin{array}{l}\text { Jurassic flint } \\
\text { Jurassic flint } \\
\text { Jurassic erratic flint }\end{array}$ & \\
\hline & $178 / 86$ & $25-45 \mathrm{~cm}$ & 1 chunk & Jurassic erratic flint & \\
\hline & $180 / 86$ & $45-65 \mathrm{~cm}$ & $\begin{array}{l}1 \text { blade (mesial part) } \\
1 \text { chunk }\end{array}$ & $\begin{array}{l}\text { Jurassic flint } \\
\text { Jurassic flint }\end{array}$ & \\
\hline 19 & $185 / 86$ & $25-45 \mathrm{~cm}$ & 1 flake from polished axe & Jurassic flint & Fig. 14: 3 \\
\hline
\end{tabular}

polished finds. All flint artefacts were made of local Jurassic raw material. Among them, there is a group of specimens made of Jurassic erratic flint of poor quality, procured from alluvial sediments in the area of the Vistula river valley (Kaczanowska and Kozłowski 1976). The inventory is devoid of cores, but there are single flakes and blades. The inventory of 


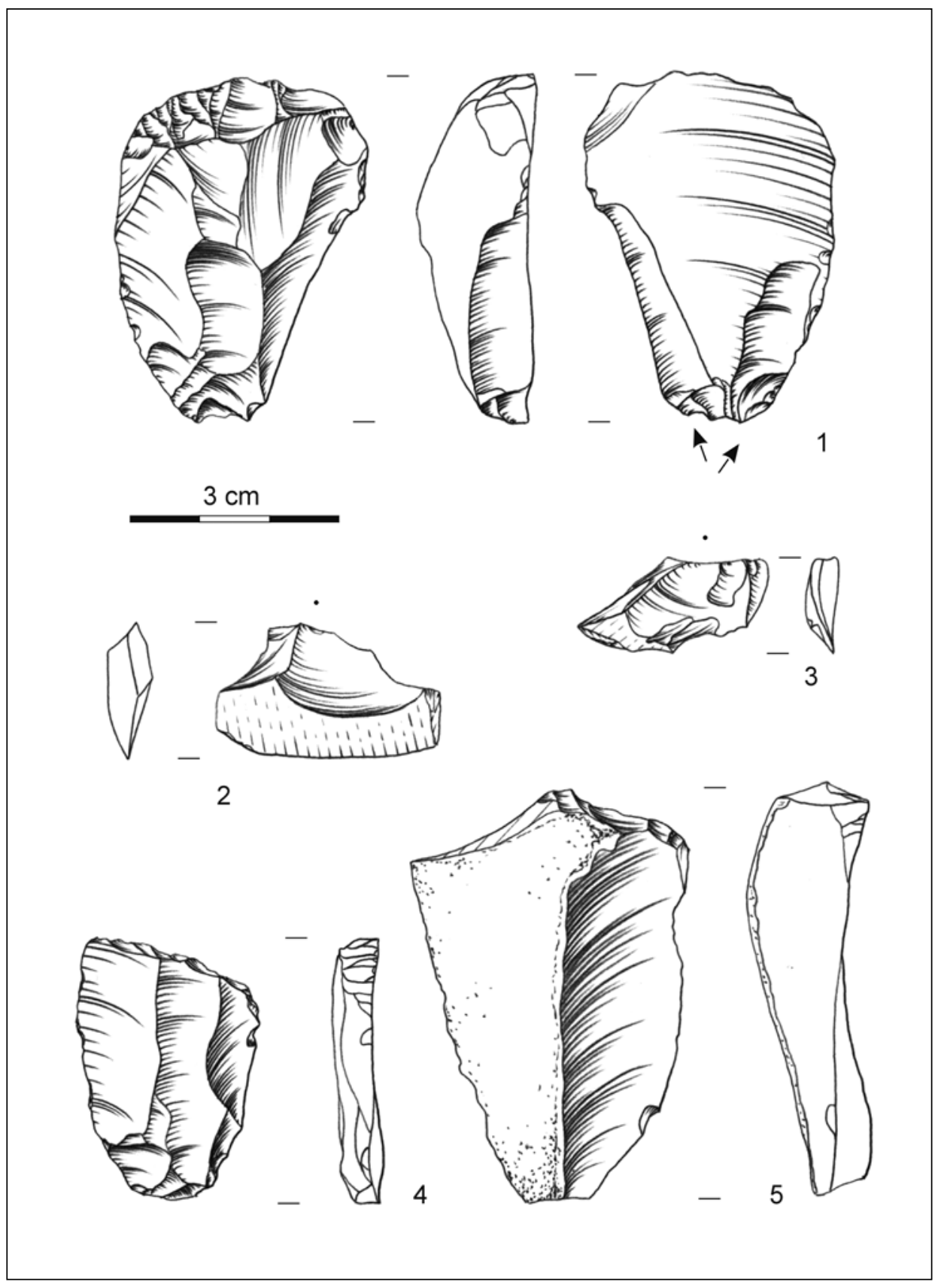

Fig. 14. Zofipole, site 1, Kraków district. Flint artefacts from features of the Baden culture: feature 15 (1-2, 4-5) and feature 19 (3). Drawn by J. Wilczyński 
retouched tools is composed of: a single end-scraper made on a partly cortical flake (Fig. 14: 5), a combination of an end-scraper and flat dihedral burin (Fig. 14: 1), an oblique truncated blade on a flake without natural surfaces (Fig. 14:4) and two flakes chipped from polished flint axes (Fig. 14: 2,3). Additionally, asingle specimen of a grinding stone and a fragment of a grindstone made of thin-grained sandstone were also found.

This assemblage of lithic artefacts is not numerous and the fact that it is composed only of specimens made of local Jurassic flint is typical of other sites of the Baden culture located in the vicinity of Kraków (Kaczanowska 1982; Rydlewski and Valde-Nowak 1980). The lack of cores, low number of discovered artefacts and using of local raw material of poor quality may indicate the extemporaneous treatment of flint artefacts (specifically the repair of worn/damaged tools) at the site. It corresponds to former findings on flint processing that tools production was carried out both in specialized flint workshops and directly in the area of settlements where it was limited to exploitation of local raw material (Balcer 1983).

\subsection{Materials to radiocarbon dating}

From two features of the Baden culture (feature 13a, 18) two samples of animal bones were taken and subjected to radiocarbon dating. Analyses were performed in the Poznan Radiocarbon Laboratory where two almost identical dates were received: $4365 \pm 25$ BP for feature 13a and 4345 \pm 35 BP for feature 18 (Fig. 15, 16). After the calibration of two measurements, more probable common time brackets for the functioning of the two analysed pits are 3082-2909 calBC (95,4\% of probability) and 3011-2921 (68,2\% of probability). These results fit in chronological frameworks of the Baden culture development in Lesser Poland and they can be linked with the Late-Classic horizon of influences of the Baden culture. Similar dates are known from Baden settlements in Iwanowice (Babia Góra) - site 1, Kraków-Witkowice - site II and Smroków - site 17 (Furholt and Machnik 2006; Zastawny 2012; Włodarczak 2013). It is noteworthy that the dates received from Zofipole are the first radiocarbon measurements achieved for settlements of the Baden culture situated on the left-bank floodplain of the Vistula river east of Kraków, between Pobiednik Wielki and Wawrzeńczyce, so on the eastern periphery of compact settlement of this culture in Lesser Poland. As sources to assessment of the character of occupation of Zofipole settlement, they prove findings in relative (ceramics) chronology on single-phase occupation of the researched settlement in Zofipole.

\subsection{Animal and human remains}

Animal remains were found at each of four features of the Baden culture discovered during excavations conducted at the site in 1986. In spite of the fact that this assemblage is not numerous (altogether 60 bone remains), it represents a very interesting and differentiated set of materials. The discussed remains were subjected to standard research 


\section{ZOFIPOLE st. 1}

\section{$4365 \pm 25 \mathrm{BP}$}

\section{feature $13 a$}
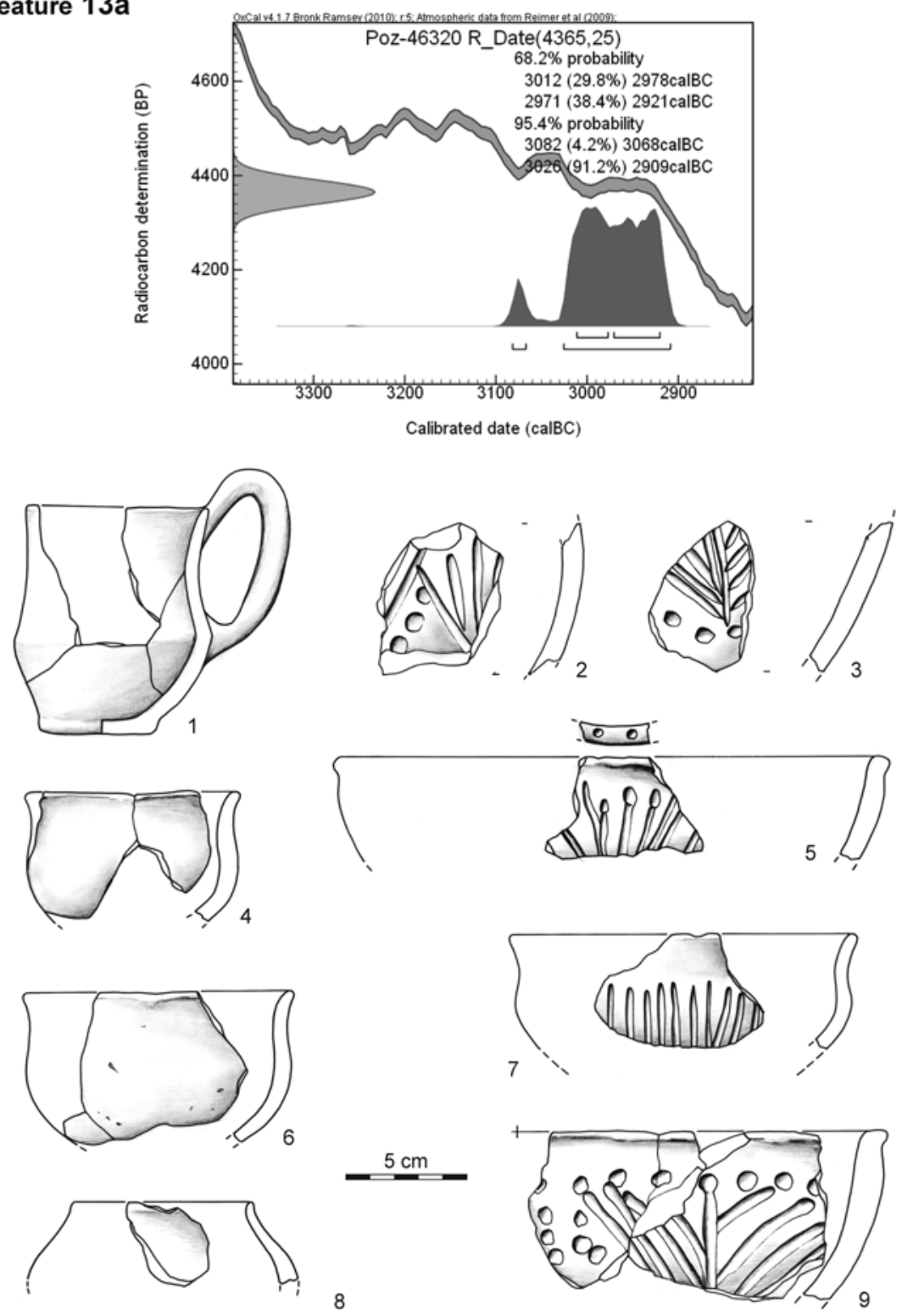

Fig. 15. Zofipole, site 1, Kraków district. The measurement of radiocarbon dating of the animal bone and characteristic artefacts from feature 13a. Drawn by A. Zastawny 


\section{ZOFIPOLE st. 1}

$4345 \pm 35$ BP feature 18
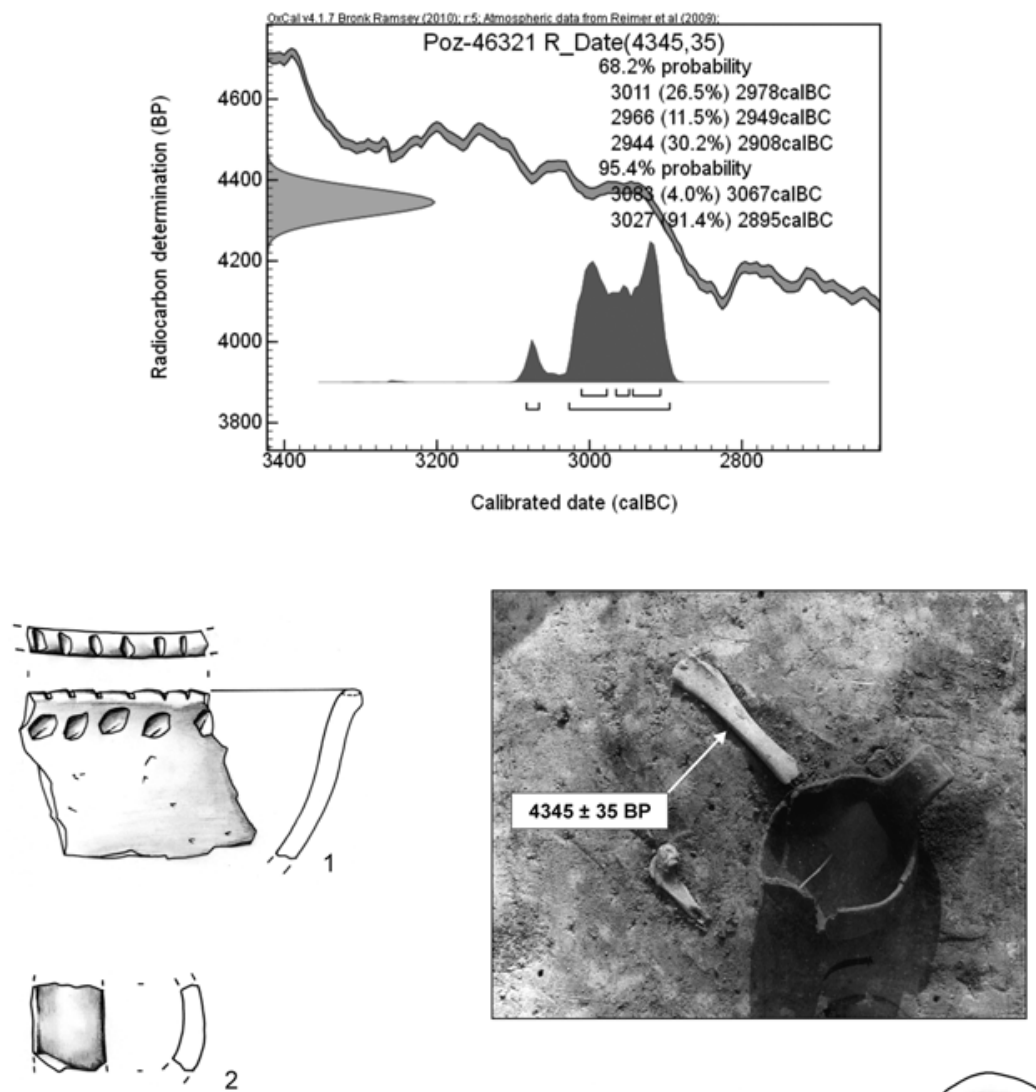

2
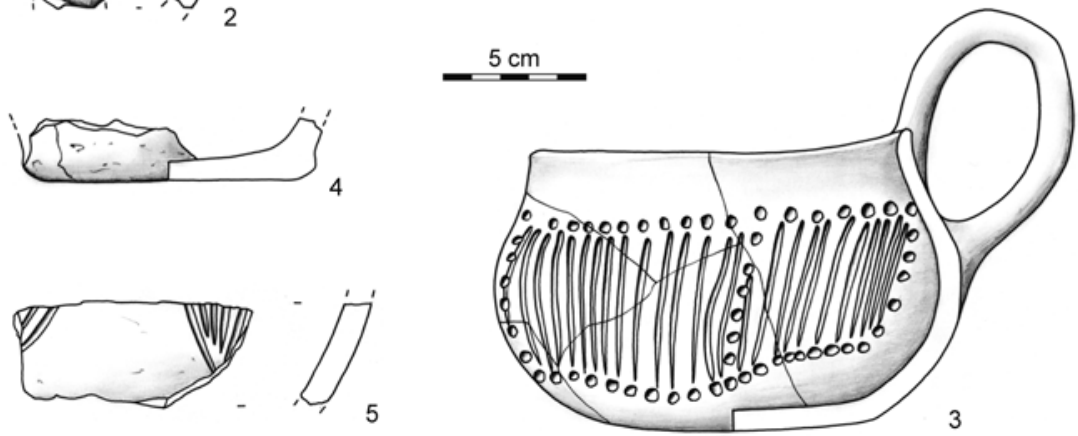

Fig. 16. Zofipole, site 1, Kraków district. The measurement of radiocarbon dating of the animal bone and characteristic artefacts from feature 18. Drawn by A. Zastawny 
procedures usually applied in archaeozoology (Reitz and Wing 1999, Lasota-Moskalewska 2007, Lyman 2008) - i.e. description of species and determination of individual elements of their skeletons. The bone remains from Zofipole site were identified on the basis of comparative materials from the collection of the Institute of Systematics and Evolution of Animals, the Polish Academy of Sciences in Kraków, and publications concerning the anatomy of mammalian species. Two quantified calculations commonly used during archeozoological studies were made of the remains - Number of Identified Specimens (NISP) and Minimum Number of Individuals (MNI). Mammal bones were also examined closely to document all possible modifications, namely the traces of processes caused by human activity - including: cut marks, percussion marks and traces of burning as well as gnawing marks made by dogs. The location of cut marks was recorded and, if it was possible, marks made during skinning, dismembering and filleting were distinguished (Binford 1981; Nillsen 2000). On account of the fragmentation of bone materials and small quantity of remains, metrical analysis was not conducted.

\subsubsection{Results}

The state of bone remains preservation is good, fragmentation and destructions noticeable on bone surfaces result from human activity (traces of burning or splitting) or carnivore modifications (gnawing marks). Only isolated bones bear traces of weathering or root etching. Among 60 remains, in case of 28 (so almost a half) it was possible to identify a species and a genre of a bone or a tooth. They derive from 5 domesticated and 1 wild species (Table 4, 5). The most numerous are pig bones (NISP=13), the remaining species are represented by isolated bones or teeth (Table 5). In a fill of feature 15, human remains were discovered: 2 incisors, a distal fragment of radius, patella and metatarsal bone. The identical

Table. 4. Number of animal remains discovered in features of the Baden culture in Zofipole, site 1, Kraków district

\begin{tabular}{|c|c|c|c|c|c|}
\hline \multirow{2}{*}{ Species } & \multicolumn{4}{|c|}{ Feature } & \multirow{2}{*}{ Total } \\
\hline & 13 & 15 & 18 & 19 & \\
\hline Cattle-Bos taurus & - & 1 & - & 1 & 2 \\
\hline Goat/sheep - Capra hircus/Ovis arries & 1 & 2 & - & - & 3 \\
\hline Pig - Sus scrofa f. domestica & 5 & 2 & 6 & - & 13 \\
\hline Dog-Canis familiaris & 2 & 1 & 1 & - & 4 \\
\hline Hamster-Cricetus cricetus & - & - & 1 & - & 1 \\
\hline Mammal of large dimensions (cattle) & 3 & 5 & 2 & - & 10 \\
\hline Mammal of medium dimensions (pig/goat/sheep) & 2 & 10 & 5 & - & 17 \\
\hline Undetermined & 3 & 3 & 4 & - & 10 \\
\hline Altogether & 16 & 24 & 19 & 1 & 60 \\
\hline
\end{tabular}


Table. 5. Animal remains with human activity traces discovered in features of the Baden culture in Zofipole, site 1, Kraków district

\begin{tabular}{|l|c|c|c|c|c|}
\hline \multicolumn{1}{|c|}{ Species } & $\begin{array}{c}\text { Number of } \\
\text { Identified } \\
\text { Specimens } \\
\text { (NISP) }\end{array}$ & $\begin{array}{c}\text { Minimal } \\
\text { Number of } \\
\text { Individuals } \\
\text { (MNI) }\end{array}$ & $\begin{array}{c}\text { Traces of } \\
\text { cutting }\end{array}$ & $\begin{array}{c}\text { Traces of } \\
\text { burning }\end{array}$ & Tools \\
\hline $\begin{array}{l}\text { Cattle } \\
\text { (Bos taurus) }\end{array}$ & 2 & 1 & - & - & - \\
\hline $\begin{array}{l}\text { Goat/sheep } \\
\text { (Capra hircus/Ovis arries) }\end{array}$ & 3 & 1 & - & 1 & 1 \\
\hline $\begin{array}{l}\text { Pig } \\
\text { (Sus scrofa f. domestica) }\end{array}$ & 13 & 2 & 3 & 1 & - \\
\hline $\begin{array}{l}\text { Dog } \\
\text { (Canis familiaris) }\end{array}$ & 4 & 1 & - & - & - \\
\hline $\begin{array}{l}\text { Hamster } \\
\text { (Cricetus cricetus) }\end{array}$ & 1 & 1 & - & - & - \\
\hline $\begin{array}{l}\text { Animal of medium dimensions } \\
\text { (pig/goat/sheep) }\end{array}$ & 17 & - & 1 & - & - \\
\hline $\begin{array}{l}\text { Animal of large dimensions } \\
\text { (cattle) }\end{array}$ & 10 & - & - & 1 & $\mathbf{1}$ \\
\hline $\begin{array}{l}\text { Undeterminable fragments of } \\
\text { bones }\end{array}$ & 10 & $\mathbf{6 0}$ & $\mathbf{6}$ & $\mathbf{4}$ & $\mathbf{3}$ \\
\hline Altogether & & - & - & - \\
\hline
\end{tabular}

colour and state of preservation of these remains as well as the fact that all of them come from an adult individual lead one to the conclusion that these bones are elements of one skeleton - most probably fragmented during prehistoric periods, nevertheless it is hard to explain why they were found in a fill of a feature of the Baden culture.

Pig remains (Sus scrofa f. domestica) are represented mainly by fragments of long limb bones and elements of the cranial skeleton /skull and mandible/ (Fig. 17). They derive from at least two specimens. On the basis of times and sequence of the eruption of teeth (Lutnicki 1972) it was possible to determine the age of a younger specimen (circa 1 year old) whereas the older one was more than 2 years old. In the course of the examination of pig remains, there were determined as follows: 2 fragments of skull, 2 fragments of mandible, molar tooth and canine, single fragment of cervical vertebrae, a distal fragment of humerus, a distal fragment of femur, a fragment of fibula and 3 fragments of tibia.

Bone remains of small ruminants (a goat or a sheep - Capra hircus/Ovis arries) $(\mathrm{NISP}=3)$ are represented by a fragment of horn core, an isolated tarsal bone and a shaft 


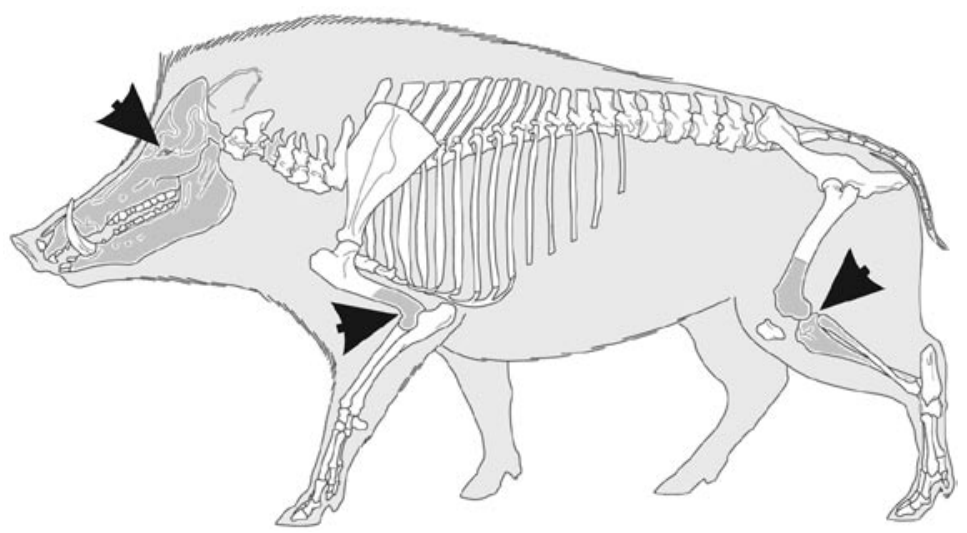

Fig. 17. Zofipole, site 1, Kraków district. The pig (Sus scrofa f. domestica) skeleton with marked on grey parts of skeleton discovered in features of the Baden culture and cut marks (marked with arrows)

of the metapodial from which an owl/perforator was made. The horn core derived from a goat was used to determine the basis of its cross-section. In the case of the remaining bones it is not possible to determine species.

Within the discussed materials, 2 bones of cattle (Bos taurus) were determined. These are: a fragment of mandible and a distal fragment of tibia deriving from a young specimen (the articular surface is not joined with diaphysis).

Dog (Canis familiaris) remains were discovered in three of the four features of the Baden culture. They are as follows: a fragment of mandible, the lower left premolar, patella and almost wholly preserved ulna with broken distal part.

It is worth mentioning that an isolated tibia of a hamster (Cricetus cricetus) was found among the bone remains registered at the site.

Within the discussed materials in case of some remains of mammals it was impossible to determine a species due to their fragmentation (lack of noticeable characteristic features). We were only able to determine the size of an animal to which individual fragments had belonged to. In such a way, 17 fragments were joined with medium sized animals (pigs or goats) and 10 fragments with animals of cattle size. The other remains (10 fragments of bones) remained undetermined.

\subsubsection{Traces of human activity and carnivore gnawing}

Bone materials deriving from 4 settlement features bear numerous traces connected with human activity. There were registered bones with cut marks (4 specimens), bones with traces of burning (3 specimens) and a fragment of which a bone tool had been made. 

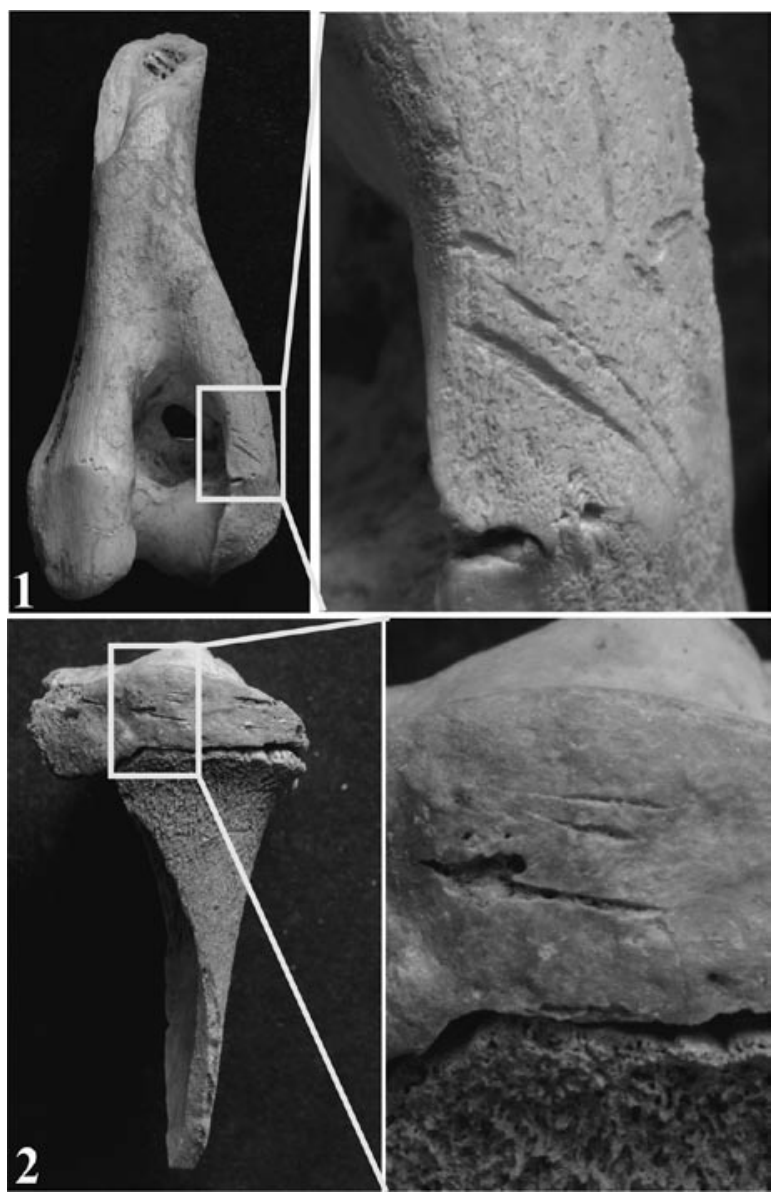

Fig. 18. Zofipole, site 1, Kraków district. Cut marks noticeable on the humerus (1) and tibia (2) of a pig (Sus scrofa f. domestica). Photo by D. Sobieraj

Cut marks noticeable on animal bones deriving from this site are linked with preparation of carcasses to consume and their consumption (Fig. 18). Such traces are visible on pig bones ( 3 specimens) and on a bone of a medium-sized animal (pig/goat). In case of pig bones, the proximal part of the tibia have distinct, crosswise marks made with a sharp tool connected with dismembering of the carcass. Signs of filleting were recorded on the distal part of the humerus whereas the inner side of the sphenoid bone of the skull (from the side of the braincase) has cut marks made most probably during the extraction of the brain. Additionally the fragment of the ilium of the medium-sized animal has marks of filleting i.e. boning before or during consumption. 
Traces of burning are noticeable on 3 bones: on unfused distal articular surface of the pig tibia, metatarsal of the goat/sheep and on a fragment of the sacral bone of a large-sized animal (most-probably cattle). These bones are partly or wholly burnt black. Such strong traces of burning did not result from roasting but rather from the accidental or intentional throwing of post-consumption wastes into the fire.

In a fill of feature 15, an isolated perforator/awl made of the metapodial of a goat or a sheep was discovered. It had been made of a longitudinal fragment of a shaft of a long bone of C-shaped cross-section. The former working edge of the tool (a point) had been formed by sanding. The grover sting is located asymmetrically compared to the axis of the tool what most probably results from the asymmetry of a bone fragment it had been originally made. Remaining edges of the perforator/awl do not bear any traces of working. A delicate polishing is noticeable on the ulna of a dog on the surface where the distal part was broken. Regrettably, it is hard to determine if this polishing is connected with intentional human activity.

Gnawing marks made by dogs are visible on 3 bones: a fragment of mandible of a dog and two pig bones: a fragment of cervical vertebrae and mandible.

\subsubsection{Archaeozoological analyses - conclusion}

In the course of the archaeozoological analyses of bone remains from 4 features of the Baden culture, 60 remains of mammals belonging to 6 species were recorded. The materials identified both on account of a species and types of a bone or a tooth constitute more than $42 \%$ of the whole material. Despite the fact that these materials are not numerous, they represent a diversified assemblage taking both on accounts of the number of species and traces of human activity visible on bones - connected with their good state of preservation. It should be emphasized that during the archaeozoological research human bone remains were found ( 2 teeth and 3 bones) deriving most probably from one individual.

Almost all of the animal remains (except the single awl) represent post-consumption waste. Pig bones are the most numerous but taking into account a small quantity of remains $(\mathrm{NISP}=60)$ results of this research should be treated with reserve. That is why it is hard to conclude on significance of particular species or structure of a herd at this site. Certainly it should be stated that the animal husbandry at Zofipole was much diversified.

As a result of the analyses conducted, we could determine that the majority of the animal remains found in Baden culture features derive from "the most consumption-valuable" body parts consumed within the site. This conclusion is based on the presence of the described parts of the skeletons of individual species and relatively numerous human traces like cut-marks. Especially noteworthy is the discovery of traces of processing resulting from the consumption of brain (cut marks recorded on the sphenoid bone of a pig skull). Within the described materials, no distal parts of limbs were found, such as metacarpals, metatarsals or phalanges. Most probably they were separated from skeletons and left in 
another part of the site where the skinning and dismembering of the carcasses was performed.

A single bone perforator/awl registered at the site has analogies in other materials of the Baden culture e.g. Kraków-Pleszów 17-20, Kraków-Zesławice 21, Kraków-Wyciąże 5 or Kraków-Witkowice II (Rook, 1971; Godłowska 1968; Kozłowski 1968; Rydlewski, ValdeNowak 1980). It is likely that tools of such a type were used not only as perforators/awls but as burins as well to ornament clay vessels.

Discoveries of dog bones registered in fills of almost each of the Baden culture features as well as traces of their activity testify to their presence at the site and their access to postconsumption remains.

Hamster bones discovered within this set of materials are particularly important because this discovery allows us to deduce the character of the environment in the closest vicinity of the site. The presence of hamster bones testifies to the presence of dry, open areas - most probably farmlands in the neighbourhood of the settlement. Nowadays, this species is met exclusively in farmlands in southern and eastern Poland (Kowalski 1971, 452). Isolated discoveries of hamster bones were as well registered at sites of the Funnel Beaker culture in Donosy and Donatkowice, KazimierzaWielka district (Makowicz-Poliszot, 2007) what may as well suggest deforestation of areas situated in the vicinity of these sites. This information corresponds to former findings concerning a settlement network in the Eneolithic period linked with the stage of reduction and concentration (Kruk, Milisauskas 1999). This phase is characterized by dense settlement located within relatively small area with intense farming and breeding around it.

\subsection{Mussel shells}

In two features of the Baden culture (features 13a and 15), 10 fragments of mussel shell were registered. They belong to Unio sp. genus, freshwater mussels from Unionidae family (unionids). Freshwater mussels are species that do not tolerate cold and occupy flowing water such as rivers, streams and creeks and water bodies with silt bottoms, ex. Uniotumidus (Piechocki, Dyduch-Falniowska 1993, 104). Small fragments of shells of this mussel are not to be classified (analyses made by W. Alexandrowicz from the Institute of Geology, AGH Kraków).

\subsection{Plant remains}

On account of the archaeo-botany, lumps of daub taken as samples from each explored feature of the Baden culture as well as the infrequent charcoals were subjected to analyses (made by M. Lityńska-Zając from the Institute of Archaeology and Ethnology of the Polish Academy of Sciences). In the analysed samples, more than 200 specimens of plant remains were designed - the most numerous derived from features 15 and 13a. In daub, 
imprints of cereals and/or blade grass (Cerealiaident. velPoaceaeident.) predominate. Their traces were registered in the materials of each pit of the discussed culture. They should be treated as traces of plant shred added to loess material used for construction purposes within the site. Numerous specimens are also the remains of spelt: emmer wheat and einkorn wheat (Triticumdicoccon vel T. monococcum). Single finds are imprints of barley (Hordeumvulgarae) and also the burnt remains of deciduous trees: poplar and willow (Populus sp. vel Salix sp.).

\section{THE RELATIVE CHRONOLOGY AND POSITION OF THE SETTLEMENT IN ZOFIPOLE AGAINST THE MICRO-REGIONAL BACKGROUND}

On the basis of the ornamentation of vessels and their characteristic forms, materials discovered at the site in Zofipole should be linked with the Late-Classic stage of the development of the Baden culture in Lesser Poland (cf. Zastawny 2011). Forms typical of this stage are present in this assemblage, i.e.: hemispherical bowls, S-shaped bowls, cups with a band-shaped handle reaching below the rim of the vessel and bulbous amphorae. Also the ornamentation is characteristic for the Late-Classic stage, including: arrangements of groves or combinations of grooves and fingertips impressions in typical of the Baden culture motives of so-called "hanging triangles" and herringbone pattern as well as plastically formed decorations, i.e.: bands with fingertips impressions stuck on the walls of amphorae. All of the mentioned types of vessels and forms of ornamentations are widespread in Late-Classic materials registered in numerous settlements of the Baden culture in the region of Kraków. Within assemblages from Zofipole, any Early-Classic features of the Baden culture were not stated such as: bipartite bowls or ornamentation of the co-called "oblique grid". Neither older elements connected with the Proto-Baden (Boleráz) horizon nor the latest (influences of the Carpathian, Post-Baden Bošáca group) traces were found at the site (cf. Zastawny 2011).

The lack of any fragments of sharp-bottomed cups (dippers) is very interesting - taking into account the fact that this form of vessel is the most typical indicator of the taxonomic position in the Zesławice-Pleszów group of the Baden culture. It should be stated that only the small part of the site in Zofipole (its eastern part) was being researched (with 4 settlement pits registered) and we presume that this characteristic may not be distinctive for all of the site. The location of the site and the overall style of ceramic production ismost similar to assemblages of the Zesławice-Pleszów group.

The settlement in Zofipole was situated in the eastern part of the reach of the Baden culture settlement in Lesser Poland. It belongs to the concentration of settlement traces situated latitudinal by a slope of the left-bank floodplain of the Vistula river, from Pobiednik Wielki up to Wawrzeńczyce (Pobiednik Wielki, Zofipole, Igołomia, Złotniki, Wawrzeńczyce). 
In this area 12 sites of the Baden culture have been registered to the present day. On the account of their distribution and topographical location, this concentration indicates close similarities to the concentration of settlement points in the area of Kraków-Nowa Huta, constituting its continuation to the east. At a close distance to the north of the discussed area in the flood-plain of the Vistula river, in the areas on the edge of the loess upland, there is one more concentration of next 12 settlement points (in the area of Stregoborzyce and Szarbia). The majority of them were discovered during surface surveys. Some of them were subjected to excavation research (Pobiednik Wielki, site 1; Zofipole - site 1; Igołomia - site 1 /Wschód and Park/; Złotniki - site 1; Wawrzeńczyce - site 41; Szarbia - site 7). Site 1 in Zofipole described is the first settlement of the Baden culture in this region that was fully elaborated the results of the research are published.

\section{FINAL CONCLUSIONS}

The archaeological research at the site in Zofipole did not cover, contrary to initial assumptions, the whole area assigned to recognition (Fig. 3). The change of decision about the location of a school to be built had caused that the research was limited to test excavations. This is the perspective that we have to bear in mind when analysing these materials. Even so, the research in Zofipole resulted in interesting and diversified sources to studies into the Baden culture in Lesser Poland.

Recognized traces of settlement may be interpreted as the part of a small, single-phase settlement, located on the loess terrace flattering by a slope of the flood-plain of the Vistula river. The size of this settlement was assessed on the basis of the discovery of only 4 settlement features in the northern part of tested area, the far from numerous ceramics artefacts in the remaining part of the area and the limitation of settled area only to the eastern part of the whole reach of site 1 in Zofipole. The western part of the site was excavated in the 1930 s and 1940 s but no Baden artefacts were discovered then. Traces of the settlement recognized in 1986 indicate the permanent character of its occupation and housing, including trapeziform storage pits (features 15 and 18) and at least one dwelling construction (feature 13a). Its discovering is worthy of mention, because in the Baden culture traces of sunken dwelling constructions are rare. Another interesting feature is a pit presumably connected with funeral rites, serving as a symbolic burial with vessels (feature 19).

The analysis of ceramic materials - while not numerous (620 fragments) - were diversified on account of typology and ornamentation - situates the settlement in Zofipole in the advanced stage of the Late-Classic horizon of the Baden culture in the Kraków region (cf. Zastawny 2011). With some reservations (see above), characteristics of vessels from settlement features link this assemblage with the Zesławice-Pleszów group of the discussed culture. The most typical indicator is the ornamentation in arrangements of grooves and holes and herringbone pattern, high number of unornamented, hemispherical cups, a rare form of a small, slender cup (jug) and most of all - the presence of pottery for salt produc- 
tion. Tiny fragments of conical beakers register in each of examined pits have analogies in materials from a settlement in Kraków-Pleszów 17-20 (Rook 1971). It is hard to determine the significance of pottery for salt production in the reconstruction of functions of the Zofipole site. For sure, this group of materials is a new source to research the issue of the gathering and distribution of salt in the Baden culture (cf. Zastawny 2014).

The late chronological position of the settlement is also testified by radiocarbon measurements for animal remains from features 13 a and 18 - i.e.: 3082-2909 calBC $(95,4 \%)$. The almost identical measurements received for both features confirms the thesis about the single-stage settlement of this site. These radiocarbon measurements are the first obtained for the concentration of sites of the Baden culture in the Vistula river valley to the east of Kraków-Nowa Huta.

The archaeozoological analyses performed are also worth mentioning because any other bone materials registered at several sites of the Baden culture in the Kraków region have so far not been elaborated in detail. In this respect, it is impossible to conduct any analyses of changes in stockherding subsistence. The state of research did not improved much with wide-scale excavation research conducted in last years in the connection with construction of A4 motorway. Against this background, the large settlement discovered at site 21 in Kraków-Zesławice is worth analysing. The roots of the research at this site are connected with 1950s. During these excavations, numerous bone materials were registered - deriving from domestic and wild animals. The stated diversities in the share of particular animals (cattle and pigs) deriving from two phases of occupation of this site (Godłowska 1968) are unambiguous and, according to Prof J. Kruk, they should be treated rather as a reflection of local changes (Kruk and Milisauskas 1999). The comparison of only the overall number of remains to determine which species prevailed is insufficient and pointless at this stage of analyses. It would be indispensable to determine the minimum number of individuals (MNI) to verify former assumptions. In bone materials from the site in Zesławice, apart from remains of livestock (cattle, pig, sheep/goat, dog) infrequent remains of wild animals registered as well - deer, roe deer, horse, bison or aurochs (Godłowska 1968). In the context of the way and scale of breeding at sites of the Baden culture, a discovery of the enclosure for cattle at this site requires special attention (Sochacki 1965; 1988). The presence of such a feature at asettlement of the Baden culture may indicate the great significance of breeding in the economy of the Baden population (Sochacki 1981). So far, conclusions regarding the increase of breeding in the late phase of the Baden culture are too early, they still should be proven with new data deriving from elaborations of bone materials from other sites of the Baden culture. Temporarily, we have only indirect indicators, i.e. in late Carpathian materials of the Baden culture figurines which presents livestock such as cattle or pigs made of clay and copper (Sochacki 1981; Horváthová 2010; Struhár et al. 2015).

The location of the site in Zofipole, on the border between two types of geo-systems (loess terrace, flood-plain), had a favourable impact on the economy of its inhabitants. The 
fertile soils of the loess terrace and abundant environment of the flood-plain were a good farming base. Remains of cereals indicate the cultivation of several species of wheat, with farmlands situated on the flattering of the loess terrace. The remains of hamster bones registered at the site indicate the presence of dry, open areas linked with farmlands (if they were not accidental) (cf. Piątkowska-Małecka 2013, 28). In the discussed period, the loess terrace of the Vistula River was deforested to a large extent. It was contrasted with humid areas of the flood-plain.

The activity of the Vistula river, crucial for the development of the flood-plain, also surely influenced the inhabitants of the settlement of the Baden culture in Zofipole. Indeed, free penetration of the river valley was difficult (comparing it with a situation in the Early Iron Age) but it was accessible in some periods, mainly in higher areas. These areas most probably provided settlers with feed for their cattle and farm animals (pig, goat/ sheep, cattle). Also discovered at the site were shells of mussels of Unio sp. species, freshwater mussels from Unionids family (Unionidae) living in old river beds, derived from the flood-plain. Examples taken from ethnology indicate that they might been gathered for consumption (feed for pigs). Shells were as well used for ornament production, they were believed to have some magical power (Wiślański 1969, 169; Zabilska 2012, 258-259, 280, references there). Forests in the flood-plain and fallen trees provided inhabitants of the settlement with material for construction purposes and firewood. A stream cutting the Pleistocene loess terrace to the east of the settlement (Fig. 1) was the source of water. Its water level was supported by a humid climate in the discussed period.

Radiocarbon measurements for materials from features 13a and 18 were suspended in the scope of a project by the National Science Centre Poland No N N109 181940. Archaeozoological and archaeo-botanical analyses are the part of the research project of the National Science Centre Poland No DEC-2013/o9/B/HS3/03401.

\section{References}

Balcer B. 1983. Wytwórczość narzędzi krzemiennych w neolicie ziem Polski. Wrocław: Ossolineum.

Balcer B. 2012. Budownictwo mieszkalne i gospodarcze $w$ neolicie ziem Polski. Warszawa: Instytut Archeologii i Etnologii PAN.

Binford L. R. 1981. Bones: ancient men and modern myths. New York: Academic Press.

Bober J. 1993. Osada kultury ceramiki promienistej w Krakowie-Nowej Hucie-Mogile w rejonie Kopca Wandy. Część I - Materiały. Materiały Archeologiczne Nowej Huty 16, 7-53.

Bober J. 1994. Osada kultury ceramiki promienistej w Krakowie-Nowej Hucie-Mogile w rejonie Kopca Wandy. Część II - Analiza. Materiaty Archeologiczne Nowej Huty 17, 13-40. 
Bober J. 1998. Najnowsze materiały kultury ceramiki promienistej ze stanowiska 5, 5A, 5B w Krakowie-Nowej Hucie (Wyciąże). Materiaty Archeologiczne Nowej Huty 21, 7-26.

Bondár M. and Raczky P. (eds.) 2009. The Copper Age cemetery of Budakalász. Budapest: Akadémiai Kiadó.

Byrska M., Fraś J., Matoga A., Pieróg I., Przybyła M. M. and Stefański D. 2006. Wstępne wyniki ratowniczych badań archeologicznych na wielokulturowych stanowiskach 8, 11, 12, 14, 15 i 20 w Krakowie-Bieżanowie, woj. Małopolskie. In Z. Bukowski (ed.), Raport 2003-2004. Wstępne wyniki konserwatorskich badań archeologicznych $w$ strefie budowy autostrad $w$ Polsce za lata 2003-2004. Warszawa: Ośrodek Ochrony Dziedzictwa Archeologicznego, 491-508.

Czekaj-Zastawny A. and Zastawny A. 2006. Badania ratownicze w Brzeziu, gm. Kłaj, stan. 17 woj. małopolskie, w latach 2003-2004. In Z. Bukowski (ed.), Raport 2003-2004. Wstępne wyniki konserwatorskich badań archeologicznych $w$ strefie budowy autostrad $w$ Polsce za lata 2003-2004. Warszawa: Ośrodek Ochrony Dziedzictwa Archeologicznego, 509-522.

Czeppe Z. and German K. 1980. Regiony fizycznogeograficzne miejskiego województwa krakowskiego. Folia Geographica, Series Geographica-Physica 13, 117-143.

Dobrzańska H. and Herbich T. 2003. Zofipole, interdisciplinary research project: fieldwork results. Archaeologia Polona 41, 91-101.

Dobrzańska H. and Kalicki T. 2003. Człowiek i środowisko w dolinie Wisły koło Krakowa w okresie od I do VII w. n.e. Archeologia Polski 48(1-2), 25-55.

Dobrzańska H. and Kalicki T. 2004. Man and environment in the Vistula river valley near Cracow from the $1^{\text {st }}$ to the $7^{\text {th }}$ century AD. In H. Dobrzańska, E. Jerem and T. Kalicki (eds.), The geoarchaeology of river valleys (= Archaeolinqua, Series Minor 18). Budapest: Archaeolingua Alapítvány, 105-141.

Furholt M. and Machnik J. 2006. Iwanowice Babia Góra I and the Settlements with Baden Ceramics in Little Poland. Questions Concerning their Duration. Iwanowice Babia Góra I i osady kultury badeńskiej w Małopolsce. Problem długości ich trwania. Sprawozdania Archeologiczne $58,325-354$

Godłowska M. 1968. Materiały z osady kultury ceramiki promienistej w Zesławicach Dłubni (Kraków-Nowa Huta) na stanowisku I. Materiaty Archeologiczne Nowej Huty 1, 91-172.

Godłowska M. 1976. Próba rekonstrukcji rozwoju osadnictwa neolitycznego w rejonie Nowej Huty. Materialy Archeologiczne Nowej Huty 10, 4-40.

Godłowska M. 1986. Neolityczne osadnictwo na stanowisku 76 w Krakowie Nowej Hucie - Branicach. Materiaty Archeologiczne Nowej Huty 10, 7-42.

Horváth T. 2012. Networks and Netwars: New perspectives on the Late Cooper Age and Early Bronze Age. Typo-chronological relationships of the Boleráz/Baden/Kostolac finds at the site of Balatonöszöd-Temetői dülő, Hungary (= British Archaeological Research. International Series 2427). Oxford: Archaeopress.

Horváthová E. 2010. Osídlenie badenskej kultúry na slovenskom území severného Potisia (= Studia Instituti Archaeologici Nitriensis Academiae Scientiarum 13). Nitra: Institut Archaeologiae, Academiae Scientiarium Slovacae. 
Informator 1987. Informator Archeologiczny. Badania rok 1986. Warszawa: ODZ.

Kaczanowska M. 1982. Z badań nad przemysłem krzemiennym kultury ceramiki promienistej. Acta Archaeologica Carpathica 22, 65-95.

Kaczanowska M. and Kozłowski J. K. 1976. Studia nad surowcami krzemiennymi południowej części Wyżyny Krakowsko-Częstochowskiej. Acta Archaeologica Carpathica 16, 201 - 219.

Kalicki T. 1991a. Holoceńskie generacje paleomeandrów Wisły w rejonie Krakowa. Kwartalnik Akademii Górniczo-Hutniczej. Geologia 17(1-2), 25-66.

Kalicki T. 1991b. The evolution of the Vistula river valley between Cracow and Niepołomice in late Vistulian and Holocene times. In L. Starkel (ed.), Evolution of the Vistula river valley during the last 15 ooo years, part IV (= Geographical Studies. Special Issue 6). Wrocław: Institute of Geography and Spatial Organization, Polish Academy of Sciences, 11-37.

Kalicki T. 2006. Zapis zmian klimatu oraz działalności czlowieka i ich rola w holoceńskiej ewolucji dolin środkowoeuropejskich (= Prace Geograficzne 204). Warszawa: Instytut Geografii i Przestrzennego Zagospodarowania Polskiej Akademii Nauk.

Kalicki T., Dobrzańska H. and Calderoni G. 2005. Paleogeografia doliny Wisły poniżej Niepołomic w okresie rzymskim. In A. Kotarba, K. Krzemień and J. Święchowicz (eds.), Wspótczesna ewolucja rzeźby Polski. VII Zjazd Geomorfologów Polskich, 19-22.09.2005. Kraków: Stowarzyszenie Geomorfologów Polskich, 171-176.

Kalicki T. Starkel L. Sala J. Soja R. and Zernickaya V. P. 1996. Subboreal paleochannel system in the Vistula valley near Zabierzów Bocheński (Sandomierz Basin). In L. Starkel (ed.), Evolution of the Vistula river valley during the last 15 ooo years, part VI (= Geographical Studies, Special Issue 9). Wrocław: Institute of Geography and Spatial Organization, Polish Academy of Sciences, 129-158.

Klimaszewski M. (ed.) 1979. Atlas miejskiego województwa krakowskiego. Kraków: Urząd Miasta Krakowa.

Kowalski S. 1971. Ssaki. Zarys teriologii. Warszawa: Wydawnictwo Naukowe PWN.

Kozłowski J. K. 1968. Materiały neolityczne i neolityczne odkryte na stanowisku Nowa Huta - Wyciąże I (badania w latach 1950-1952). Materiaty Archeologiczne Nowej Huty 1, 13-90.

Krąpiec M. 1996. Dendrochronology of "black oaks" from river valleys in Southern Poland. In L. Starkel (ed.), Evolution of the Vistula river valley during the last 15 ooo years, part VI (= Geographical Studies, Special Issue 9). Wrocław: Institute of Geography and Spatial Organization, Polish Academy of Sciences, 61-78.

Kruk J. and Milisauskas S. 1999. Rozkwit i upadek spoleczeństw rolniczych neolitu. Kraków: Instytut Archeologii i Etnologii PAN.

Lasota-Moskalewska A. 2007. Archeozoologia. Ssaki. Warszawa: Wydawnictwo Uniwersytetu Warszawskiego.

Lutnicki W. 1972. Uzębienie zwierząt domowych. Warszawa: Państwowe Wydawnictwo Naukowe.

Makowicz-Poliszot D. 2007. Fauna of the Upper Vistula River Basin - An Analysis Based On Bone Material From Selected Sites of the Funnel Beakers Culture. Sprawozdania Archeologiczne $59,143-180$. 
Nilssen P. J. 2000. An actualistic butchery study in South Africa and its implications for reconstructing hominid strategies of carcass acquisition and butchery in the Upper Pleistocene and Plio-Pleistocene. Cape Town: Departament of Archaeology, University of Cape Town.

Nosek S. 1967. Zarys historii badań archeologicznych w Matopolsce (= Prace Komisji Archeologicznej Oddziału PAN w Krakowie 7). Wrocław: Ossolineum.

Piątkowska-Małecka J. 2013. Łowiectwo ssaków na ziemiach polskich od neolitu do okresu wędrówek ludów. Warszawa: Instytut Archeologii UW.

Piechocki A. and Dyduch-Falniowska A. 1993. Mięczaki (Mollusca). Małże (Bivalvia). Warszawa: Państwowe Wydawnictwo Naukowe.

Reitz E.J. and Wing E.S. 1999. Zooarchaeology. Cambridge: Cambridge University Press.

Rook E. 1971. Materiały kultury ceramiki promienistej odkryte na stanowisku Nowa Huta Pleszów (badania w latach 1954-1963). Materialy Archeologiczne Nowej Huty 4, 111-234.

Rook E. 1980. Osadnictwo neolityczne w jaskiniach Wyżyny Krakowsko-Częstochowskiej. Materiały Archeologiczne 20, 5-130.

Rydlewski J. and Valde-Nowak P. 1980. Neolityczne i eneolityczne stanowisko Kraków-Witkowice II w świetle badań w 1976 r. Sprawozdania Archeologiczne 32, 103-113.

Sochacki Z. 1965. Ślady późnoneolitycznej zagrody dla bydła (?) w Dłubni-Zesławicach, pow. Kraków. Wiadomości Archeologiczne 31, 154-158.

Sochacki Z. 1971. Über die Badentung der Siedlung in Grodkowice /Kleinpolen/ zur Problematik der Kultur der Radialverzierzierten Keramik. Acta Archaeologica Carpathica 12, 49-59.

Sochacki Z. 1981. Z zagadnień ekonomiczno-społecznych kultury ceramiki promienistej w Europie. Archeologa Polski 26(1), 41-70.

Sochacki Z. 1988. Zespót osadniczy kultury ceramiki promienistej w Krakowie-Zestawicach. Warszawa: Wydawnictwo Uniwersytetu Warszawskiego.

Starkel L. Gębica P. Niedziałkowska E. and Podgórska-Tkacz A. 1991. Evolution of both the Vistula floodplain and lateglacial-early Holocene palaeochannel systems in the Grobla Forest (Sandomierz Basin). In L. Starkel (ed.), Evolution of the Vistula river valley during the last 15 ooo years, part IV (= Geographical Studies, Special Issue 6). Wrocław: Institute of Geography and Spatial Organization, Polish Academy of Sciences, 87-99.

Struhár V., Soják M. and Cheben M. 2015. The Baden culture hilltop settlements in Northern Slovakia and their "socio-symbolic" Importance. In M. Nowak and A. Zastawny (eds.), The Baden culture around the western Carpathians (= Via Archaeologica). Kraków: Krakowski Zespół do Badań Autostrad, 275-310.

Tyczyńska M. 1968. Rozwój geomorfologiczny terytorium miasta Krakowa (=Zeszyty Naukowe UJ, Prace Geograficzne 17. Kraków: Uniwersytet Jagielloński.

Wiślański T. 1969. Podstawy gospodarcze plemion neolitycznych $w$ Polsce pótnocno-zachodniej. Wrocław: Ossolineum.

Włodarczak P. 2013. Projekt badań chronologii absolutnej eneolitu i początków epoki brązu w Małopolsce. In I. Cheben and M. Soják (eds.), Otázky neolitu a eneolitu našich krajín - 2010. Nitra: Archeologický ústav Slovenskej akadémie vied, 373-387. 
Zabilska M. 2012. Depozyty ze szczątkami mięczaków na stanowiskach kultury łużyckiej z Polski. Charakterystyka i próba określenia ich genezy. Acta Universitatis Nicolai Copernici. Archeologia 32, 253-289.

Zastawny A. 1999. Uwagi na temat chronologii osadnictwa kultury badeńskiej w zachodniej części Małopolski. Sprawozdania Archeologiczne 51, 9-55.

Zastawny A. 2000. Kultura badeńska w regionie wielicko-bocheńskim - stan i problematyka badań. Sprawozdania Archeologiczne 52, 9-42.

Zastawny A. 2006. Osadnictwo społeczności badeńskiego kręgu kulturowego w Jurze Ojcowskiej. In J. Lech and J. Partyka (eds.), Jura Ojcowska w pradziejach i w początkach państwa polskiego. Ojców: Ojcowski Park Narodowy. Muzeum im. prof. Władysława Szafera, 439-458.

Zastawny A. 2009. Obrządek pogrzebowy kultury badeńskiej. In A. Czekaj-Zastawny (ed.), Obrzq̨dek pogrzebowy kultur pochodzenia naddunajskiego $w$ neolicie Polski potudniowo-wschodniej (5600/550o-29oo BC). Kraków: Instytut Archeologii i Etnologii PAN, 159-170.

Zastawny A. 2011. Chronologia i formy oddziaływań kompleksu badeńskiego w Małopolsce/ Chronologie a formy vlivů badenského komplexu v Malopolsku. In M. Popelka and R. Šmidtová (eds.), Otázky neolitu a eneolitu našich zemí - 2009 (= Praehistorica 29). Praha: Ústav pro archeologii FFUK Praha, 431-449.

Zastawny A. 2012. Chronologia absolutna kultury badeńskiej w późnym neolicie Matopolski /31oo2900 BC/. Kraków (unpublished report stored in Narodowe Centrum Nauki: grant N N109 181940).

Zastawny A. 2014. Neolityczne osadnictwo strefy „piaskowej” południowego obrzeżenia doliny Wisły pod Krakowem w świetle badań na stanowisku 13 w Kokotowie, gm. Wieliczka, woj. małopolskie. Raport 9, 11-52.

Żaki A. 1949. Pierwszy pewny w Polsce grób kultury ceramiki promienistej. Sprawozdania z czynności i posiedzeń Polskiej Akademii Umiejętności 50, 647-650. 